\title{
The Shallow and Deep Western Boundary Circulation of the South Atlantic at $5^{\circ}-11^{\circ} S$
}

\author{
Friedrich A. Schott, Marcus Dengler, Rainer Zantopp, Lothar Stramma, Jürgen Fischer, And \\ PETER BRANDT \\ IFM-GEOMAR Leibniz-Institut für Meereswissenschaften an der Universität Kiel, Kiel, Germany
}

(Manuscript received 13 January 2005, in final form 6 May 2005)

\begin{abstract}
Repeated shipboard observation sections across the boundary flow off northeastern Brazil as well as acoustic Doppler current profiler (ADCP) and current-meter records from a moored boundary array deployed during $2000-04$ near $11^{\circ} \mathrm{S}$ are analyzed here for both the northward warm water flow by the North Brazil Undercurrent (NBUC) above approximately $1100 \mathrm{~m}$ and the southward flow of North Atlantic Deep Water (NADW) underneath. At $5^{\circ} \mathrm{S}$, the mean from nine sections yields an NBUC transport of $26.5 \pm 3.7$ $\mathrm{Sv}\left(\mathrm{Sv} \equiv 10^{6} \mathrm{~m}^{3} \mathrm{~s}^{-1}\right)$ along the boundary; at $11^{\circ} \mathrm{S}$ the mean NBUC transport from five sections is $25.4 \pm 7.4$ $\mathrm{Sv}$, confirming that the NBUC is already well developed at $11^{\circ} \mathrm{S}$. At both latitudes a persistent offshore southward recirculation between 200- and 1100-m depth reduces the net northward warm water flow through the $5^{\circ} \mathrm{S}$ section (west of $31.5^{\circ} \mathrm{W}$ ) to $22.1 \pm 5.3 \mathrm{~Sv}$ and through the $11^{\circ} \mathrm{S}$ section to $21.7 \pm 4.1 \mathrm{~Sv}$ (west of $32.0^{\circ} \mathrm{W}$ ). The 4-yr-long NBUC transport time series from $11^{\circ} \mathrm{S}$ yields a seasonal cycle of $2.5 \mathrm{~Sv}$ amplitude with its northward maximum in July. Interannual NBUC transport variations are small, varying only by $\pm 1.2 \mathrm{~Sv}$ during the four years, with no detectable trend. The southward flow of NADW within the deep western boundary current at $5^{\circ} \mathrm{S}$ is $25.5 \pm 8.3 \mathrm{~Sv}$ with an offshore northward recirculation, yielding a nine-section mean of $20.3 \pm 10.1 \mathrm{~Sv}$ west of $31.5^{\circ} \mathrm{W}$. For Antarctic Bottom Water, a net northward flow of $4.4 \pm 3.0 \mathrm{~Sv}$ is determined at $5^{\circ} \mathrm{S}$. For the $11^{\circ} \mathrm{S}$ section, the moored array data show a pronounced energy maximum at 60-70-day period in the NADW depth range, which was identified in related work as deep eddies translating southward along the boundary. Based on a kinematic eddy model fit to the first half of the moored time series, the mean NADW transfer by the deep eddies at $11^{\circ} \mathrm{S}$ was estimated to be about 17 Sv. Given the large interannual variability of the deep near-boundary transport time series, which ranged from 14 to $24 \mathrm{~Sv}$, the $11^{\circ} \mathrm{S}$ mean was considered to be not distinguishable from the mean at $5^{\circ} \mathrm{S}$.
\end{abstract}

\section{Introduction}

The western boundary regime of the tropical South Atlantic Ocean is a crossroads of important meridional transfers of warm and cold water masses. As part of the meridional overturning circulation (MOC) of the Atlantic, approximately $17-20 \mathrm{~Sv}\left(\mathrm{~Sv} \equiv 10^{6} \mathrm{~m}^{3} \mathrm{~s}^{-1}\right)$ of North Atlantic Deep Water (NADW) pass southward through the equatorial zone, compensated by a net northward transport of warm and intermediate waters and of Antarctic Bottom Water (Lux et al. 2001; Ganachaud 2003; Lumpkin and Speer 2003). Furthermore, the upper-layer western boundary flow, carried by the North Brazil Undercurrent (NBUC), is a crucial link within the Atlantic subtropical cell (STC) connecting

Corresponding author address: Dr. Friedrich Schott, IFMGEOMAR Leibniz-Institut für Meereswissenschaften, Düsternbrooker Weg 20, 24105 Kiel, Germany.

E-mail: fschott@ifm-geomar.de the subduction regions of the subtropical South Atlantic and the eastward equatorial and off-equatorial undercurrents that supply the equatorial and eastern boundary upwelling regimes (Malanotte-Rizzoli et al. 2000; Zhang et al. 2003; Snowden and Molinari 2003; Schott et al. 2004). In addition to the shallow and deep overturning cells, the transport pattern of the tropical South Atlantic is complicated by the southward crossequatorial Sverdrup transport, of the order of $10 \mathrm{~Sv}$ (depending on the wind stress climatology used, Mayer et al. 1998; Townsend et al. 2000), that also requires northward compensating return flow along the western boundary. While large decadal variations of the interior thermocline flow convergence have been detected in the Pacific Ocean STC (McPhaden and Zhang 2004), the much scarcer database for the tropical Atlantic so far has not allowed corresponding estimates of Atlantic STC variability (M. McPhaden 2004, personal communication).

Observations of the South Atlantic western boundary regime have been carried out over the past years by 


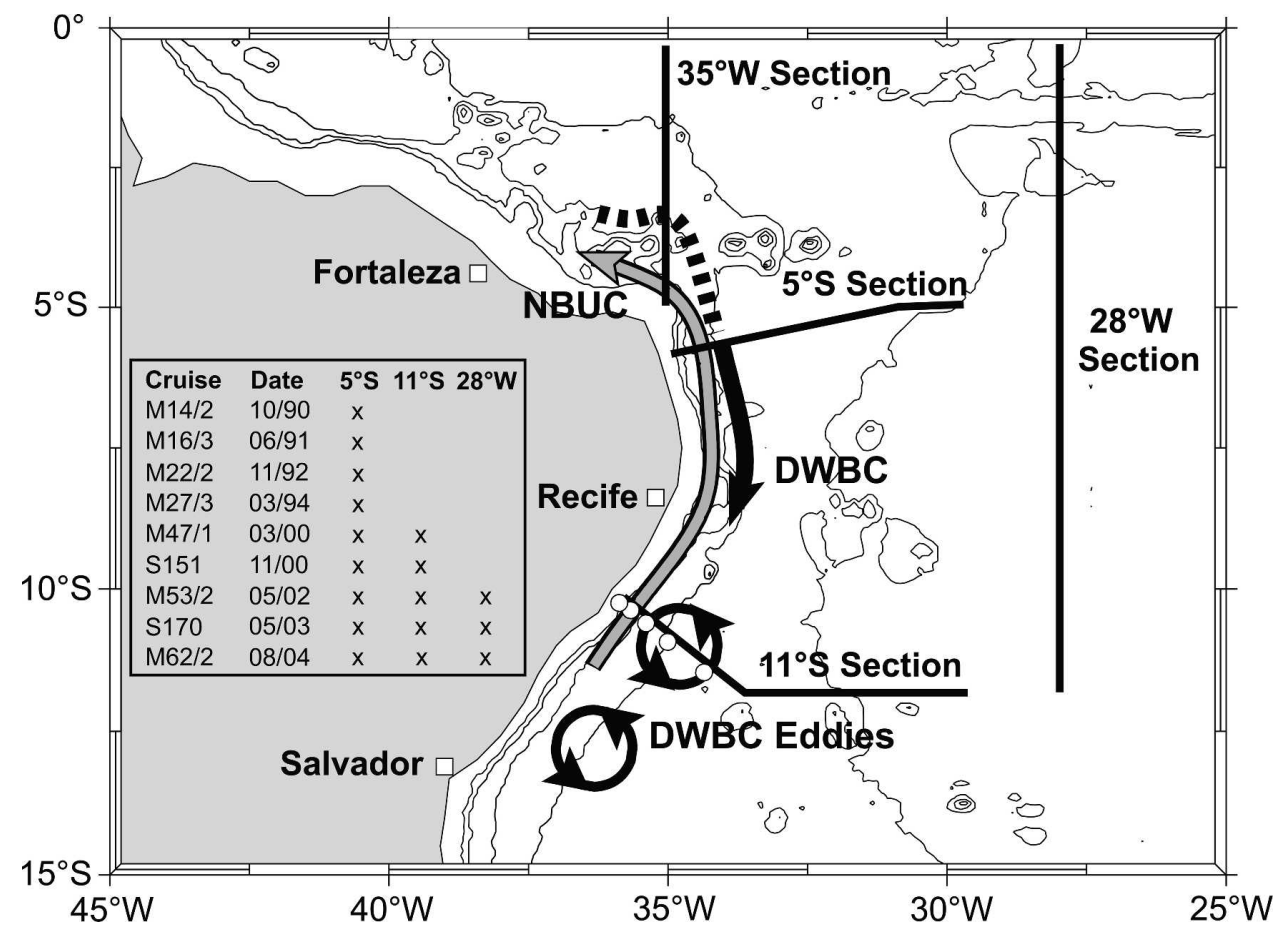

FIG. 1. Sections across the boundary currents, location of moored array near $11^{\circ} \mathrm{S}$ (circles), and schematic paths of the North Brazil Undercurrent (NBUC) and South Atlantic Deep Western Boundary Current (DWBC); inset shows times and cruise identifiers of shipboard observations along $5^{\circ}$ and $11^{\circ} \mathrm{S}$ sections. Disintegration of the DWBC south of about $8^{\circ} \mathrm{S}$ into a sequence of migrating eddies is indicated as derived by Dengler et al. (2004). Also shown are the meridional sections along $35^{\circ}$ and $28^{\circ} \mathrm{W}$ used for the discussion of results.

repeated shipboard hydrography and current-profiling sections at two latitudes, near $5^{\circ}$ and about $11^{\circ} \mathrm{S}$, and by a moored array at $11^{\circ} \mathrm{S}$ (Fig. 1). A total of nine sections from $5^{\circ} \mathrm{S}$ and five sections from $11^{\circ} \mathrm{S}$ are available and analyzed here. The boundary current work started during the World Ocean Circulation Experiment (WOCE) with four $5^{\circ} \mathrm{S}$ sections during 1990-94 (Schott et al. 1998) and was continued as part of the German Climate Variability and Predictability (CLIVAR) program with five sections during 2000-04. While the moored array at $11^{\circ} \mathrm{S}$ was deployed from March 2000 to August 2004 with the main objective of observing NBUC variability that might potentially be related to STC variability, it was also instrumented to observe the deep flow.

An earlier note on the boundary circulation near $5^{\circ} \mathrm{S}$ (Schott et al. 2002) presented initial results on the mean $5^{\circ} \mathrm{S}$ transport from six sections available at that time and discussed pathways of Argo floats drifting at shallow depths. A related recent analysis (Schott et al. 2003) concentrated on the meridional section along $35^{\circ} \mathrm{W}$ (Fig. 1) from which 13 ship sections by different research groups were available. The mean section of zonal transports composed from these observations will play a role in the following for the interpretation of how the boundary regime might be connected to the largerscale circulation of the tropical regime.

A large-scale survey off the Brazilian coast from several sections in November 2000 was presented by Stramma et al. (2005). They observed an exceptional situation that the NBUC at $11^{\circ} \mathrm{S}$ was weak relative to the mean at $5^{\circ} \mathrm{S}$ and that a stronger than normal inflow from the east appeared between $11^{\circ}$ and $5^{\circ}$ S. Seasonal variability in the upper North Atlantic Deep Water (uNADW) at the $5^{\circ} \mathrm{S}$ section was described from chlorofluorocarbon (CFC) measurements by Rhein and Stramma (2005). They found that the boreal spring CFC signal in the UNADW was weaker than in boreal autumn. The latest piece of analysis (Dengler et al. 2004, referred to as D04 hereinafter) focused on the NADW layer. Noticing in the moored time series at $11^{\circ} \mathrm{S}$ an energy maximum with a period of about 2 months at the NADW level, they determined from the combined moored and shipboard dataset and highresolution numerical model analysis that the NADW transport at $11^{\circ} \mathrm{S}$ is not being accomplished by a continuous boundary current but by a sequence of migrating eddies. The related model analysis suggested that the DWBC becomes unstable near $8^{\circ} \mathrm{S}$. 
Here we present the complete set of current and transport observations from the $5^{\circ}$ and $11^{\circ} \mathrm{S}$ shipboard surveys and the moored array. A reprocessing of the current profiles obtained by lowered acoustic Doppler current profilers (LADCPs) during the earlier cruises with an improved analysis technique increased the quality of the earlier results reported in Schott et al. (2002). Transports are determined for seven density layers selected to distinguish between the different upper-layer NADW and Antarctic Bottom Water (AABW) water masses. For the lower NBUC layer, a substantial offshore counterflow is found and other evidence is studied to ascertain its possible origin. For the DWBC, the complete set of $5^{\circ} \mathrm{S}$ sections allows now a good estimate of its composition in density space as it enters the South Atlantic, and a drastic transformation is found from its distribution when entering the equatorial region as a near-zonal flow across the $35^{\circ} \mathrm{W}$ section just a short distance farther north (Fig. 1).

At $11^{\circ} \mathrm{S}$, the moored array can be used to calculate a 4-yr-long transport time series for the NBUC from which its seasonal cycle will be extracted and compared with other evidence, as well as estimates of its intraseasonal to interannual variability. The D04 derivation of the upstream DWBC eddy disintegration showed that transport time series from our array from near the continental slope will yield rectified means of the swirl velocities associated with the eddies. The magnitude of the rectification in shipboard sections and moored data will be estimated.

This presentation is structured as follows: In section 2 we describe the observations and analysis methods, and in section 3 the results on layer transports at $5^{\circ} \mathrm{S}$ from our nine sections and at $11^{\circ} \mathrm{S}$ from five sections. Section 4 discusses the NBUC variability, based on the 4 -yr-long moored time series from the $11^{\circ} \mathrm{S}$ array. DWBC variability at both sites is the subject of section 5 , and in the discussion, section 6 , we compare our results with other available evidence.

\section{The observations}

\section{a. Shipboard measurements}

A total of nine ship surveys of the near-equatorial western boundary regime were carried out from $\mathrm{R} / \mathrm{V}$ Meteor and R/V Sonne during 1990-2004. All surveys included the $5^{\circ} \mathrm{S}$ section, which was actually slanted from $5^{\circ} 40^{\prime} \mathrm{S}$ near the coast at $35^{\circ} \mathrm{W}$ to $5^{\circ} 0^{\prime} \mathrm{S}$ at $31^{\circ} \mathrm{W}$ (Fig. 1). Results on the mean flow at $5^{\circ} \mathrm{S}$ from six sections obtained until 2001 were presented in the brief report of Schott et al. (2002). Here we show an update that also differs in the deep currents and transports from those earlier results because of improved process- ing of the LADCP, as explained below. The section near $11^{\circ} \mathrm{S}$ was carried out five times along exactly the same slanted track parallel to the moored currentmeter array during 2000-04 (Fig. 1) and analyzed for the deep current structure by D04.

\section{1) HYdROGRAPHY}

The CTD work was carried out either with Neil Brown NB3 CTD or Seabird SBE 9 CTD systems. The accuracy for all cruises was $0.002^{\circ}-0.003^{\circ} \mathrm{C}$ for temperature and $0.0020-0.0025$ for salinity. The data are used here to compose mean hydrographic sections for $5^{\circ}$ and $11^{\circ} \mathrm{S}$ and to derive density surfaces for separating the different flow layers.

The upper-layer water masses along the western subtropical boundary are marked first by the salinity maximum of the Subtropical Underwater (STUW) at the top of the thermocline near $100 \mathrm{~m}$ (Fig. 2), which decreases from the $11^{\circ}$ to the $5^{\circ} \mathrm{S}$ section (Fig. 3), then by fresher (relative to the interior) values of the South Atlantic Central Water (SACW) layer down to about $400 \mathrm{~m}$, followed by the salinity minimum of the Antarctic Intermediate Water (AAIW) near $700 \mathrm{~m}$. There is also a temperature minimum at about $3.8^{\circ} \mathrm{C}$ near the boundary (Fig. 3), caused by the upper Circumpolar Deep Water (uCDW) that contributes the deepest part of the northward-moving upper limb off northern Brazil (Reid 1989). Isopycnals selected in the following to subdivide the water masses of the upper limb are $\sigma_{\theta}=$ $24.5 \mathrm{~kg} \mathrm{~m}^{-3}$ for separating the surface water from the upper thermocline waters, and $\sigma_{\theta}=26.8 \mathrm{~kg} \mathrm{~m}^{-3}$ as the lower level of the water supplying the Equatorial Undercurrent (EUC) (Schott et al. 1998). The lower boundary of the upper limb or warm water circulation is defined here at $\sigma_{1}=32.15 \mathrm{~kg} \mathrm{~m}^{-3}$, also following earlier studies (Rhein et al. 1995; Schott et al. 2002). Although there is a meridional flow reversal near that depth close to the boundary, allowing this isopycnal to be selected for referencing geostrophy there, we will see below that the direct current observations suggest a more zonally slanted zero contour farther offshore for separating the upper and lower limb transports.

The NADW along the boundary is marked by a salinity maximum (Fig. 3), as well as by oxygen and other tracer maxima (e.g., Reid 1989; Rhein et al. 1995). We separate the upper, middle, and lower NADW layers by the isopycnals $\sigma_{2}=37.00 \mathrm{~kg} \mathrm{~m}^{-3}$ and $\sigma_{4}=45.83 \mathrm{~kg}$ $\mathrm{m}^{-3}$, respectively. The separation between the lower NADW and the AABW is defined by $\sigma_{4}=45.90 \mathrm{~kg} \mathrm{~m}^{-3}$.

\section{2) Shipboard ADCP}

During the 14 years of surveys, tremendous developments occurred regarding shipboard current profiling 


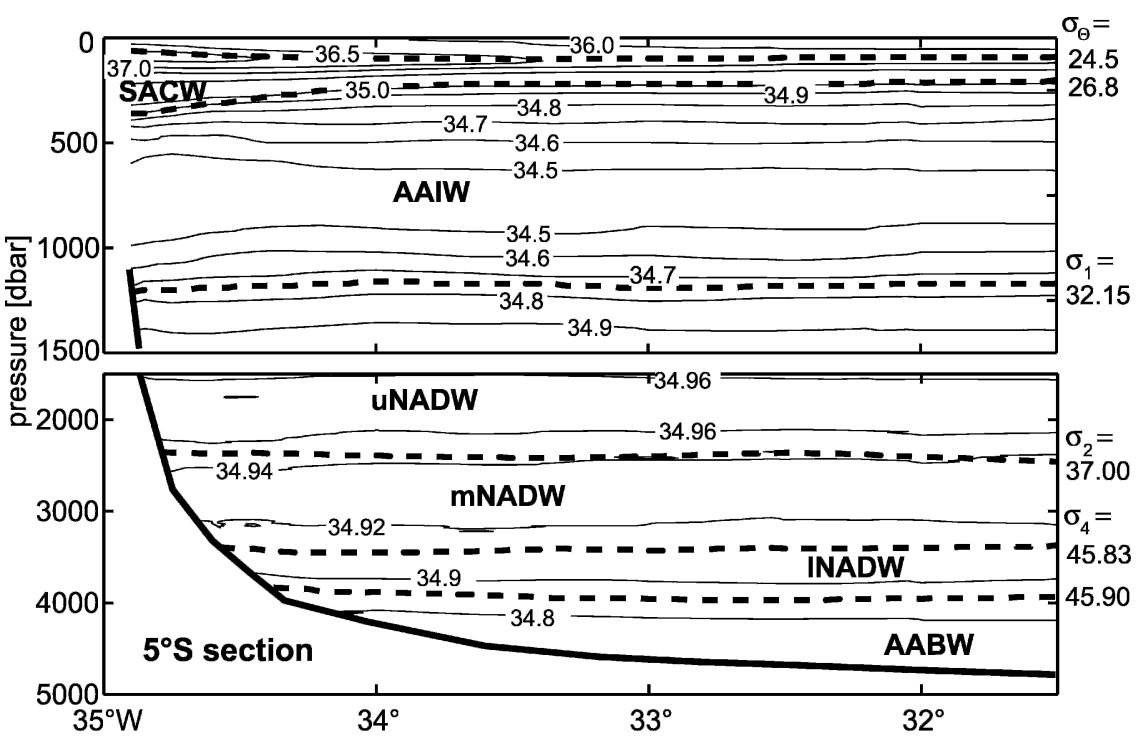

FIG. 2. Mean salinity section from nine CTD surveys along the $5^{\circ} \mathrm{S}$ line with superimposed isopycnals used in our analysis for separating the flow layers; depth scale expanded for upper $1500 \mathrm{~m}$.

techniques. All cruises used here had some kind of shipboard ADCP operating, beginning with a $150-\mathrm{kHz}$ RD Instruments system with a depth range limited to about $250 \mathrm{~m}$ installed in the ship's well in 1990 and leading finally to the ocean surveyor (OS) $75-\mathrm{kHz}$ RDI phased array with 700-m depth range (Fischer et al. 2003) or even $1200 \mathrm{~m}$ with the OS system working at $38 \mathrm{kHz}$. At the same time, the positioning accuracy, a basic requirement of shipboard profiling, evolved from occasional satellite positions to continuous GPS tracking with much higher accuracy. Similarly, the ship's heading can now be much more precisely determined, with the changes from gyrocompasses to GPS antennas.

After applying standard postprocessing routines, the data were averaged onto a grid along the section with a separation of $0.05^{\circ}$ in longitude. Tidal analysis from the moored stations at $11^{\circ} \mathrm{S}$ had yielded only small harmonic amplitudes $\left(<1 \mathrm{~cm} \mathrm{~s}^{-1}\right)$ and tidal corrections were therefore not considered necessary. The accuracy of hourly averaged horizontal velocities for underway recording is estimated to be better than $4 \mathrm{~cm} \mathrm{~s}^{-1}$ for all instruments. For average on-station velocities, which are also used to constrain the LADCP data (see below), the accuracy is estimated to be better than $2.0 \mathrm{~cm} \mathrm{~s}^{-1}$ for typical station durations of about $2 \mathrm{~h}$.

\section{3) Lowered ADCP and Pegasus}

Different sampling strategies were used to measure deeper currents throughout the observational program.
During the early (pre 1994) cruises, a Pegasus profiler was used during CTD stations (Schott et al. 1998), by which the current profile was derived from measuring the position of a free-falling float with acoustic bottom transponders. During the later cruises, an ADCP was lowered together with the CTD at all stations.

The LADCP instrument used during most of the later cruises was a deep sea version of the classical 150$\mathrm{kHz}$ narrowband $\mathrm{ADCP}$ of RD Instruments. In August 2004, one upward and one downward looking $300-\mathrm{kHz}$ ADCP were used simultaneously along the $5^{\circ} \mathrm{S}$ section. During postprocessing, the average velocity profile was calculated from the individual profiles of one cast by solving an inverse problem, similar to the procedure described by Visbeck (2002), but including upper-ocean velocities, collected simultaneously by the vessel-mounted ADCPs while on station, to additionally constrain the solution of the inverse problem. This methodology reduces low baroclinic mode errors in the average velocity profile because the constraints from bottom track velocities and from upper ocean currents collected by the vessel-mounted ADCP force the average profile to be in agreement with these additional and more accurate data. We estimate that the accuracy of the LADCP data, usually assumed to be about $5 \mathrm{~cm} \mathrm{~s}^{-1}$, is better than $4 \mathrm{~cm} \mathrm{~s}^{-1}$ in this study.

For the calculation of velocity sections for each individual cruise, the Pegasus and LADCP profiles of each section were linearly interpolated onto the same hori- 

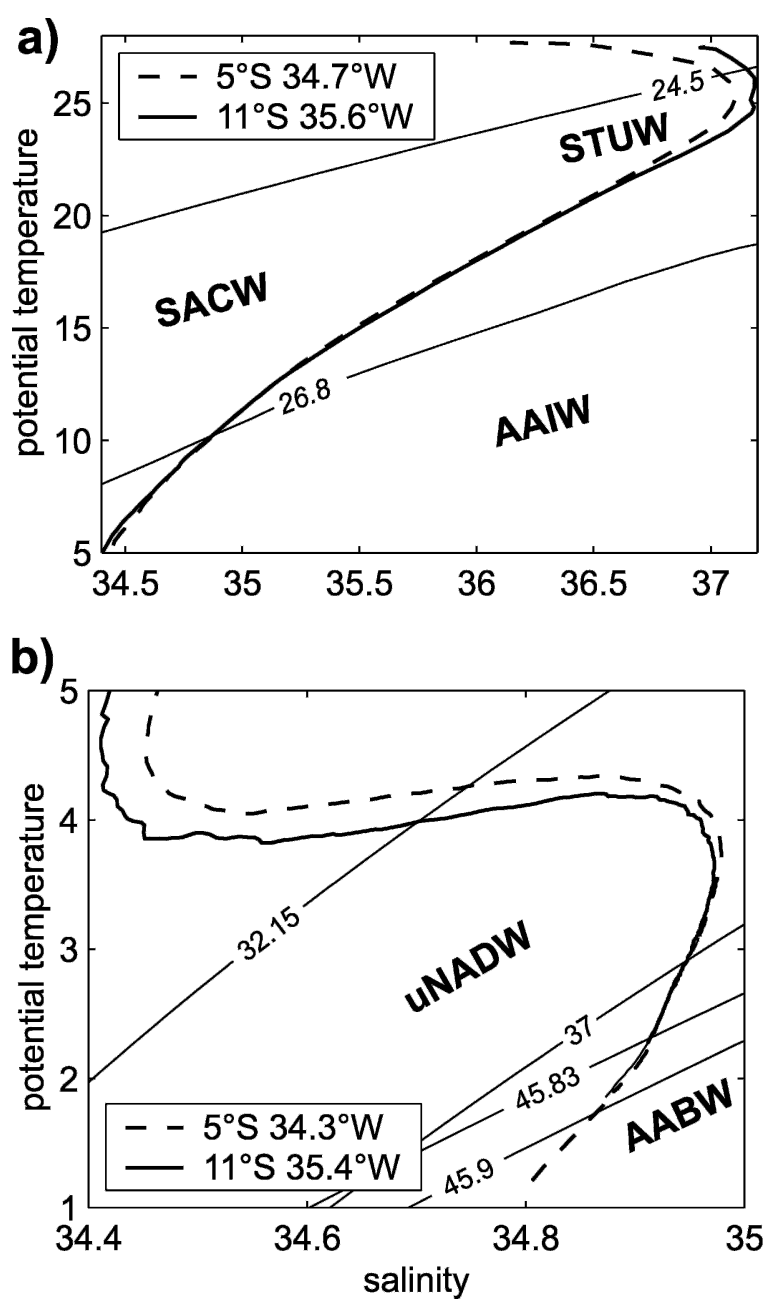

FIG. 3. Mean $\theta-S$ diagrams from the (a) shallow and (b) deep boundary currents of the $11^{\circ} \mathrm{S}$ (solid) and $5^{\circ} \mathrm{S}$ (dashed) sections. Isopycnals shown are those from Fig. 2; identified water masses are STUW: Subtropical Underwater, SACW: South Atlantic Central Water, AAIW: Antarctic Intermediate Water, uNADW: upper North Atlantic Deep Water, and AABW: Antarctic Bottom Water.

zontal grid as used for the shipboard ADCP data. Both direct-velocity datasets were then merged, applying a weight ratio of 5:1 for shipboard ADCP data because of their higher accuracy and better horizontal resolution. Last, a Gaussian-shaped interpolation, having horizontal and vertical influence and cutoff scales of $0.05^{\circ}$ and $30 \mathrm{~m}$ and $0.15^{\circ}$ and $50 \mathrm{~m}$, respectively, was used for surface and near-bottom extrapolation.

\section{4) LAYER TRANSPORTS}

For each ship section, layer transports were calculated between the isopycnals chosen above. Transports were calculated from the current components normal to the zonally slanted sections, that is, toward $349^{\circ} \mathrm{T}$ at $5^{\circ} \mathrm{S}$ and toward $36^{\circ} \mathrm{T}$ at $11^{\circ} \mathrm{S}$. The near-boundary, offshore, and net transports in each layer were determined. For the mean of the nine sections at $5^{\circ} \mathrm{S}$ and five sections at $11^{\circ} \mathrm{S}$, respectively, layer transports were calculated between the isopycnal depths calculated from the mean hydrographic sections. The standard deviations of the mean transports given below are calculated from the individual layer transports, based on isopycnal depths during the individual surveys.

\section{b. The moored array observations at $11^{\circ} \mathrm{S}$}

\section{1) Instruments AND DATA RETRIEVAL}

The array, consisting of five moorings, K1-K5, was first deployed in March 2000 on Meteor cruise M47/1 (Fig. 4, Table 1), then stations K2 and K4 were exchanged in November 2000 (Sonne cruise S151). The full array was retrieved in February 2002 [by National Oceanic and Atmospheric Administration (NOAA) Ship Ron Brown] and K1-K4 were deployed until May 2003 (cruise S170) and then again until August 2004 (cruise M62/2). The near-surface flow at stations K1K3 was covered by upward-looking ADCPs, while K4 carried an acoustic current meter at about 100-m depth. Except for the latest deployment, May 2003 to August 2004, where $\mathrm{K} 1$ and $\mathrm{K} 2$ were equipped with $75-\mathrm{kHz}$ Longranger ADCPs (approximately 500-m range), all prior deployments were with $150-\mathrm{kHz}$ narrowband ADCPs (approximately 350-m range). Station K5 was only installed from March 2000 to February 2002 for observing the offshore deep flow and only reached up to the 1500-m level (Fig. 4).

At the deeper levels, currents were recorded by Aanderaa rotor current meters and by acoustic current meters (ACMs). Two types of ACMs were used, Sontek (Argonaut) and Falmouth Scientific Instruments (FSI), respectively. All current meters were equipped with temperature sensors. In addition, some Seabird Electronics Seacat and Microcat recorders were installed for salinity observations at core depths of different water masses. Mooring motion was estimated by ADCP distance measurements to the surface and by pressure recorders at selected depths. During the first deployments, we experienced some unpleasant instrument losses due to corrosion of mooring elements, although that technology had worked rather well elsewhere. No losses occurred in the final deployment and the reasons for the earlier malfunctions remain unexplained. Fortunately, some instruments, including valuable records, were retrieved by Brazilian fishermen or navy vessels (Table 1). Overall, the dataset allows 


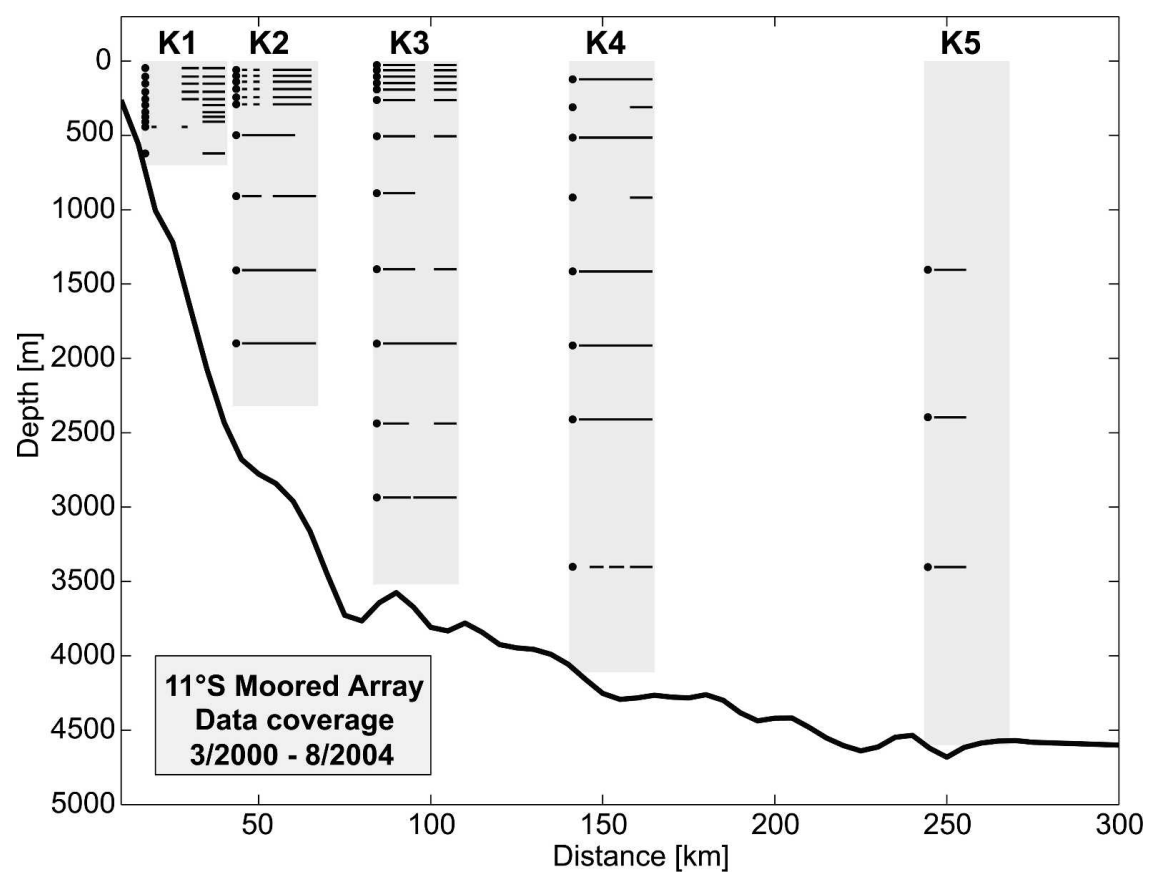

FIG. 4. Moored array K1-K5 installed off Brazil near $11^{\circ} \mathrm{S}$ from March 2000 to August 2004 (indicated by shading) with instrument distribution and record retrieval (horizontal bars); see text for details.

composition of a mean moored current section from records of different lengths over the 4-yr observational period and construction of meaningful transport time series.

\section{2) Current Records}

Selected time series from the upper layer at stations K1-K4 (Fig. 5a; Table 1) show the northward NBUC, with its core near position $\mathrm{K} 2$, reaching down to about the 900-m level (Table 1) and hardly ever reversing at the core location. Its mean maximum of about 65 $\mathrm{cm} \mathrm{s}^{-1}$ in the ADCP measurements is reached at 180 250-m depth (Table 1). An interesting feature is the mean southward flow at 300-900-m depth offshore from the NBUC, at station K4 (bottom of Fig. 5a, Table 1), to which we will come back.

Within NADW levels, the surprising finding was that very large intraseasonal fluctuations occur, particularly during the first phase of the recordings (Fig. 5b). The mean southward flow has a maximum of $14 \mathrm{~cm} \mathrm{~s}^{-1}$ at the 1900-m level of station K3 and, but there are also multiple periods with northward flow along the continental slope. Several of the ship surveys took place while maximum southward flow off the continental slope was occurring (Figs. 5b,c; survey times indicated by the dashed lines). At the deepest and farthest off- shore station, K5, the mean flow at the NADW level is weakly northward (Table 1), and the fluctuations are predominantly out of phase in relation to the stations near the boundary (Fig. 5c).

\section{3) Section composition And transport CALCULATION FROM MOORED DATA}

Several methods were used to compose mean sections and to derive transport variability and annual cycles. First, a mean section was determined from the data of Table 1, using mapping based on Gaussian weights with horizontal mapping scales ranging from 20 $\mathrm{km}$ near the boundary to $100 \mathrm{~km}$ offshore and vertically from $100 \mathrm{~m}$ in the upper layer to $500 \mathrm{~m}$ below $1500 \mathrm{~m}$. This yielded reasonable comparison with the betterresolved ship section transports, as shown below.

The losses of several mooring segments (e.g., Fig. 5a) required filling of the gaps. The lack of obvious trends and changes in the statistics justified calculating EOFs from the gappy records of all available alongshore currents of the entire array and then using those for filling the record gaps, rather than some other kind of interpolation. The first four EOFs were used for this procedure. Since we were only interested in transport variability on time scales longer than weeks, the augmented time series were low-passed again with a 10-day filter 
TABLE 1. Mooring positions and current-meter instrumentation for the $11^{\circ} \mathrm{S}$ array between March 2000 and August 2004. Current vectors are rotated along the coastline, and $v$ is positive toward $036^{\circ}$ true.

\begin{tabular}{|c|c|c|c|c|c|c|c|c|}
\hline \multirow[b]{2}{*}{ Station } & \multirow[b]{2}{*}{ Lat/lon/bottom } & \multirow[b]{2}{*}{ Depth (m) } & \multirow[b]{2}{*}{ Record length (days) } & $\bar{u}$ & $\delta u$ & $\bar{v}$ & $\delta v$ & \multirow[b]{2}{*}{$\operatorname{EKE}\left(\mathrm{cm}^{2} \mathrm{~s}^{-2}\right)$} \\
\hline & & & & \multicolumn{4}{|c|}{ Rotated $036^{\circ}\left(\mathrm{cm} \mathrm{s}^{-1}\right)$} & \\
\hline \multirow[t]{11}{*}{ K1 } & $10^{\circ} 16.0^{\prime} \mathrm{S}$ & 48 & 815 & -1.8 & 3.8 & 23.9 & 15.0 & 119.6 \\
\hline & $35^{\circ} 51.7^{\prime \prime} \mathrm{W}$ & 104 & 815 & -1.1 & 2.9 & 36.1 & 12.8 & 86.3 \\
\hline & $900 \mathrm{~m}$ & 152 & 815 & -0.9 & 2.9 & 41.1 & 13.7 & 98.2 \\
\hline & & 208 & 815 & -1.2 & 2.8 & 44.8 & 13.8 & 99.1 \\
\hline & & 256 & 815 & -1.4 & 2.8 & 45.8 & 14.1 & 102.8 \\
\hline & & 296 & 467 & -1.4 & 2.5 & 44.4 & 13.4 & 93.3 \\
\hline & & 344 & 467 & -1.3 & 2.3 & 42.1 & 12.7 & 83.0 \\
\hline & & 376 & 467 & -1.0 & 2.2 & 39.7 & 12.2 & 76.7 \\
\hline & & 408 & 467 & -1.0 & 2.0 & 36.4 & 12.0 & 74.1 \\
\hline & & 443 & 172 & 1.2 & 2.8 & 31.4 & 14.7 & 111.9 \\
\hline & & 622 & 467 & -0.5 & 1.9 & 16.6 & 8.2 & 35.5 \\
\hline \multirow[t]{10}{*}{ K2 } & $10^{\circ} 22.8^{\prime} \mathrm{S}$ & 60 & 988 & 5.1 & 7.5 & 46.7 & 17.0 & 172.7 \\
\hline & $35^{\circ} 40.8^{\prime} \mathrm{W}$ & 100 & 988 & 6.5 & 7.9 & 56.6 & 14.7 & 139.3 \\
\hline & $2320 \mathrm{~m}$ & 140 & 988 & 7.4 & 8.3 & 63.6 & 12.2 & 108.7 \\
\hline & & 188 & 988 & 7.5 & 8.8 & 67.3 & 11.2 & 101.0 \\
\hline & & 244 & 988 & 7.4 & 8.7 & 66.5 & 11.5 & 104.3 \\
\hline & & 292 & 988 & 7.3 & 8.7 & 64.5 & 11.8 & 107.8 \\
\hline & & 499 & 1140 & 2.0 & 6.8 & 44.7 & 10.3 & 76.4 \\
\hline & & 909 & 1321 & 3.0 & 3.9 & 16.4 & 9.2 & 49.9 \\
\hline & & 1407 & 1594 & -0.8 & 2.1 & -1.6 & 8.4 & 37.5 \\
\hline & & 1899 & 1605 & -0.5 & 3.9 & -8.1 & 11.4 & 72.6 \\
\hline \multirow[t]{12}{*}{ K3 } & $10^{\circ} 36.7^{\prime} \mathrm{S}$ & 27 & 1150 & -1.2 & 11.7 & 15.5 & 14.0 & 166.4 \\
\hline & $35^{\circ} 23.4^{\prime} \mathrm{W}$ & 62 & 1150 & 0.5 & 9.0 & 22.5 & 11.8 & 110.8 \\
\hline & $3520 \mathrm{~m}$ & 105 & 1150 & 1.1 & 7.2 & 26.6 & 9.6 & 72.0 \\
\hline & & 149 & 1150 & 1.8 & 5.6 & 28.5 & 7.9 & 47 \\
\hline & & 192 & 1150 & 2.5 & 4.9 & 28.8 & 7.0 & 36.6 \\
\hline & & 262 & 1150 & 2.6 & 4.8 & 24.7 & 7.2 & 37.7 \\
\hline & & 506 & 1150 & 1.4 & 6.2 & 6.8 & 11.3 & 82.9 \\
\hline & & 888 & 684 & -1.3 & 3.5 & -3.1 & 6.2 & 25.0 \\
\hline & & 1400 & 1150 & -2.2 & 6.5 & -9.4 & 10.9 & 81.2 \\
\hline & & 1900 & 1607 & -2.4 & 9.1 & -13.9 & 14.5 & 146.4 \\
\hline & & 2438 & 1014 & -1.5 & 5.7 & -11.5 & 13.0 & 100.7 \\
\hline & & 2936 & 1518 & -0.2 & 5.1 & -6.7 & 9.0 & 53.8 \\
\hline \multirow[t]{8}{*}{ K4 } & $10^{\circ} 56.5^{\prime} \mathrm{S}$ & 123 & 1602 & -3.2 & 6.5 & 5.7 & 8.1 & 53.6 \\
\hline & $34^{\circ} 59.5^{\prime} \mathrm{W}$ & 310 & 464 & 0.5 & 7.0 & -1.5 & 8.4 & 59.3 \\
\hline & 4110 m & 515 & 1602 & -0.6 & 11.0 & -6.8 & 11.9 & 131.4 \\
\hline & & 919 & 464 & -0.6 & 6.7 & -5.7 & 7.3 & 49.2 \\
\hline & & 1416 & 1602 & -2.1 & 8.4 & -4.5 & 8.9 & 74.9 \\
\hline & & 1913 & 1602 & -2.6 & 11.8 & -4.8 & 11.7 & 137.9 \\
\hline & & 2410 & 1601 & -2.6 & 9.5 & -4.3 & 10.1 & 96.8 \\
\hline & & 3402 & 1035 & -0.4 & 6.5 & -2.1 & 6.7 & 43.5 \\
\hline \multirow[t]{3}{*}{ K5 } & $11^{\circ} 28.2^{\prime} \mathrm{S}$ & 1404 & 685 & 0.6 & 8.8 & 4.2 & 8.0 & 70.8 \\
\hline & $34^{\circ} 12.9^{\prime} \mathrm{W}$ & 2397 & 685 & 1.6 & 10.7 & 3.2 & 10.6 & 112.7 \\
\hline & $4600 \mathrm{~m}$ & 3404 & 685 & -0.7 & 5.9 & -0.5 & 5.1 & 30.4 \\
\hline
\end{tabular}

and then mapped into sections every 2.5 days. In addition, tests were made in which additional gaps were introduced and the EOFs recalculated for the reduced dataset. The reconstructed gappy time series closely resembled the original records, showing that the method worked reasonably well. Based on the mean sections of shipboard and moored observations, we then defined boxes encompassing the different flow structures for calculating transport time series across the $11^{\circ} \mathrm{S}$ section. 

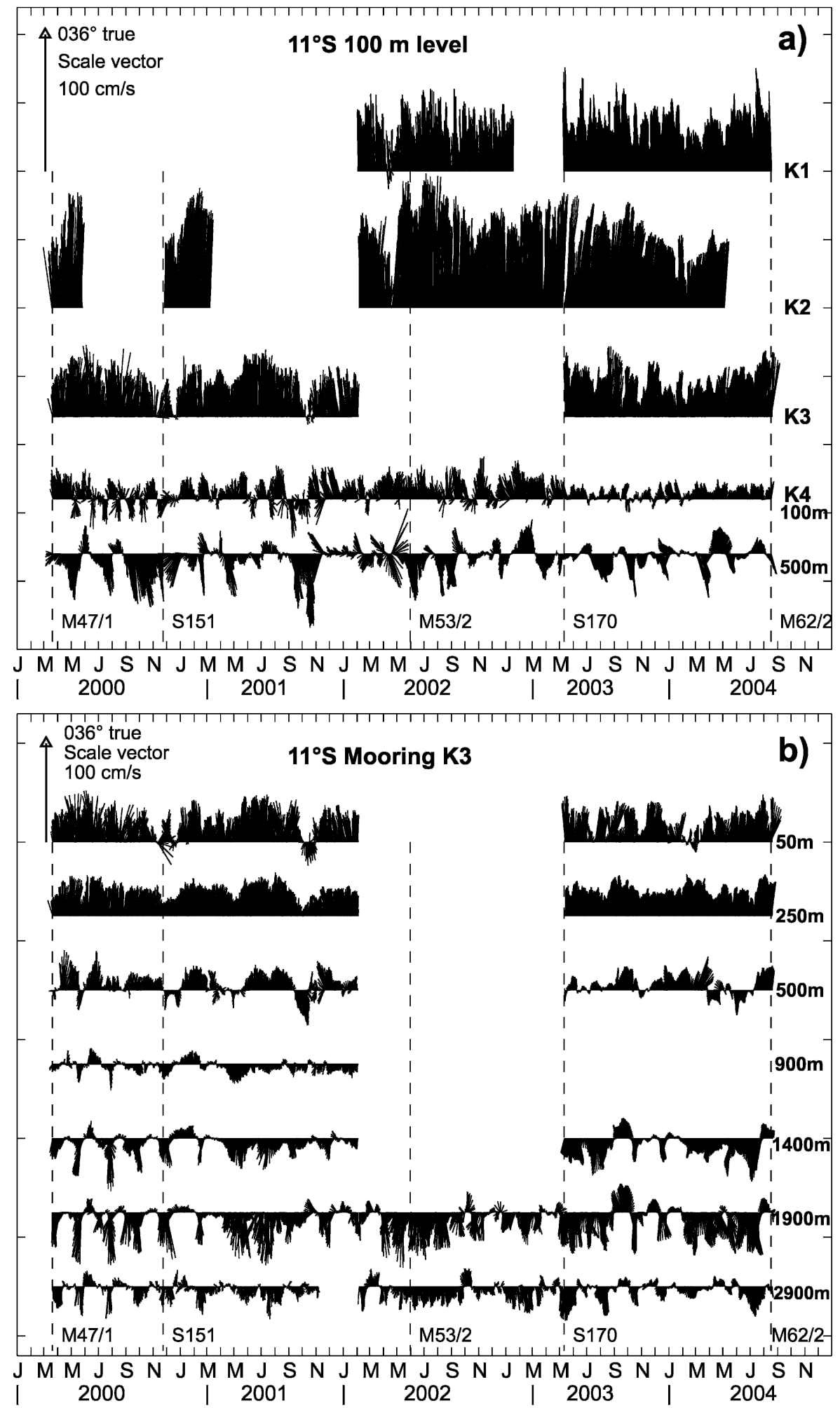

FIG. 5. Time series of 40-h low-passed current vector plots (up $=36^{\circ} \mathrm{T}$, parallel to topography; Fig. 1) from selected instrument levels: (a) upper-layer near $100 \mathrm{~m}$ for stations K1-K4 across the array and the 500-m record at $\mathrm{K} 4$, (b) vertical distribution at central mooring $\mathrm{K} 3$, and (c) at 1900-m level for stations K2-K5. Also shown (dashed vertical lines) are times when ship observations along the $11^{\circ} \mathrm{S}$ section were taken. 


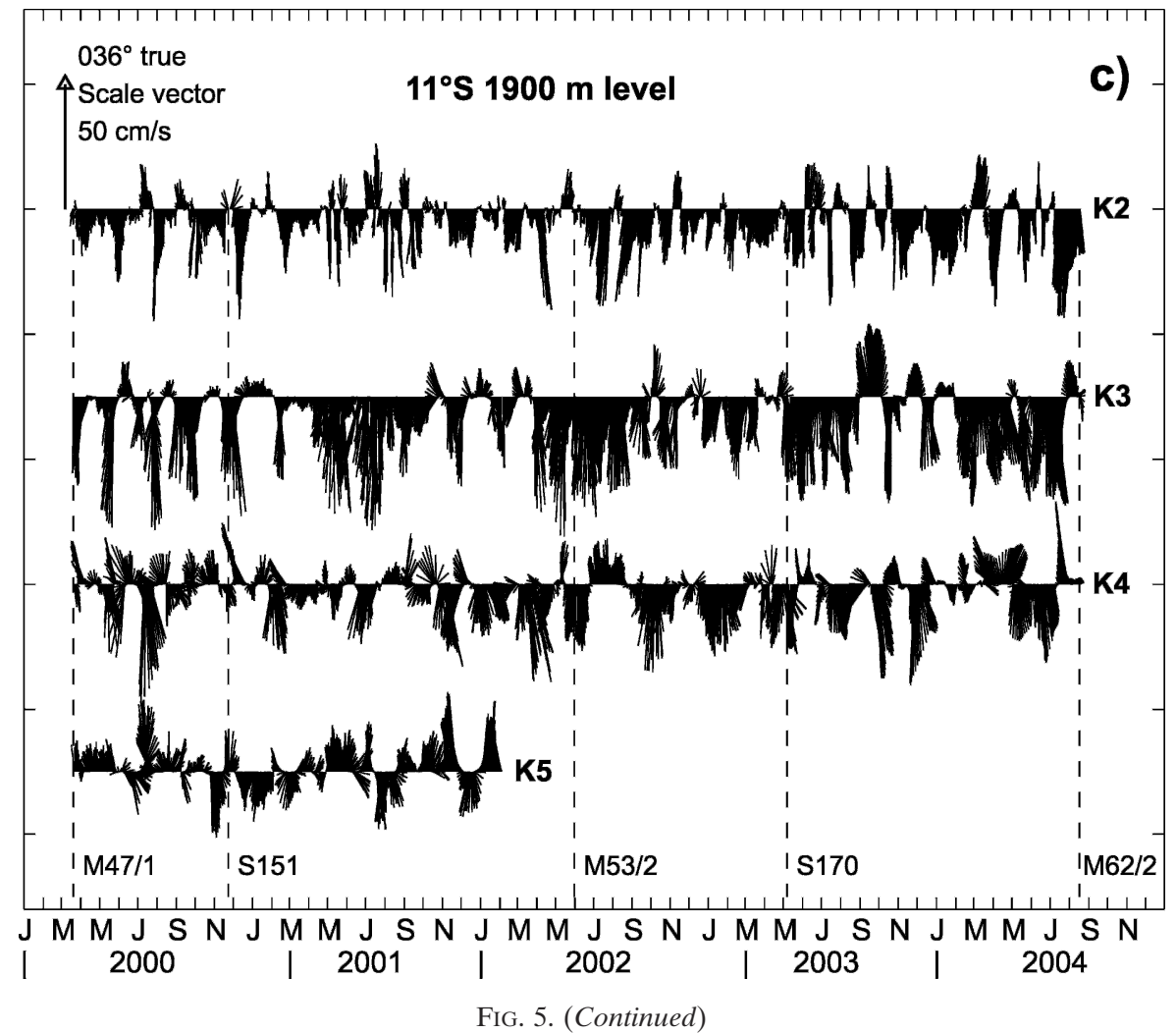

3. The mean boundary current structure at $5^{\circ}$ and $11^{\circ} \mathrm{S}$

\section{a. Circulation at $5^{\circ} \mathrm{S}$}

\section{1) UPPER LIMB}

The nine individual velocity sections (Fig. 6a) show that the NBUC at $5^{\circ} \mathrm{S}$ is deep-reaching, to about $1000 \mathrm{~m}$ and always attached to the boundary, with the current core located approximately over the $1500-\mathrm{m}$ isobath. The shelf is very shallow west of the section, and velocities there were found to be weak in shipboard ADCP measurements so that only very small amounts of transports are unaccounted for by the transport sections presented here.

The total NBUC flow above the $\sigma_{1}=32.15 \mathrm{~kg} \mathrm{~m}^{-3}$ isopycnal varies from 23 to $34 \mathrm{~Sv}$ among the individual surveys (west of the red-dashed line, Fig. 6a), and the mean northward boundary current transport above that isopycnal is $26.5 \pm 3.7 \mathrm{~Sv}$ (Table 2a). In the density range of $\sigma_{\theta}=24.5-26.8 \mathrm{~kg} \mathrm{~m}^{-3}$, which supplies the EUC (Schott et al. 1998), the NBUC is widest and its mean northward transport is $14.2 \pm 2.4 \mathrm{~Sv}$. In the third layer, which includes the lower SACW, the AAIW, and uCDW, the mean transport is $8.9 \pm 1.5 \mathrm{~Sv}$ (Fig. 7a, Table 2a). Near the surface, $3.4 \pm 1.6 \mathrm{~Sv}$ of very shallow flow are estimated to pass northward, but it should be noted that currents in the top $30 \mathrm{~m}$, where the bulk of the (southward) Ekman flow occurs, have to be estimated from extrapolation.

The addition of three more sections leaves the estimate of the mean NBUC transport nearly unchanged relative to the six-section mean of $25 \pm 4.4 \mathrm{~Sv}$ reported in the earlier analysis of Schott et al. (2002). What is now more obvious is that there is substantial southward flow offshore from the NBUC in the third (lower CW/ AAIW) layer (Fig. 7a) with a mean of $5.2 \pm 4.9 \mathrm{~Sv}$ (Table 2a). With the error of the mean at $\pm 0.8 \mathrm{~Sv}$ from the nine independent sections, this counterflow in the third layer is significant. It reduces the total net northward flow through the section west of $31^{\circ} 30^{\prime} \mathrm{W}$ and above $\sigma_{1}=32.15 \mathrm{~kg} \mathrm{~m}^{-3}$ to $22.1 \pm 5.3 \mathrm{~Sv}$ (Fig. 7a, Table 2a). It has to be pointed out that the sectionwide integrals given here follow from the practical limitation of our sections, rather than from any particular physical insight, and that additional offshore flows are both possible and likely.

\section{2) NADW LAYER}

All nine sections show a southward deep nearboundary current with the velocity maximum typically 

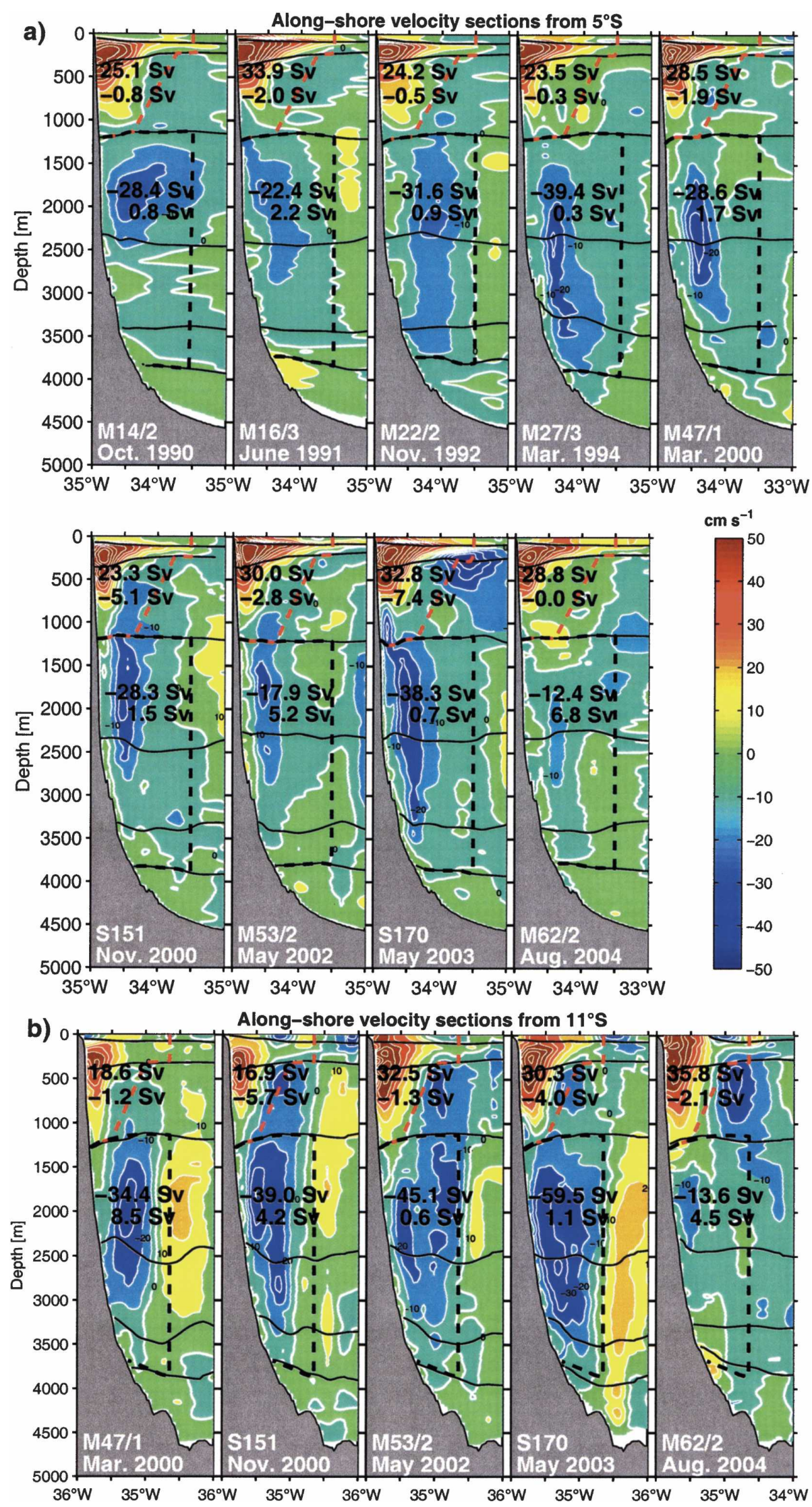
TABLE 2. Transports (Sv) of upper-layer water masses across $5^{\circ}$ and $11^{\circ} \mathrm{S}$ from ship sections.

\begin{tabular}{|c|c|c|c|c|}
\hline Density layer & $<24.5$ & $24.5-26.8$ & $26.8-32.15$ & Total \\
\hline \multicolumn{5}{|c|}{ (a) $5^{\circ} \mathrm{S}$ nine sections } \\
\hline Boundary & 3.4 & 14.2 & 8.9 & 26.5 \\
\hline Std dev & 1.6 & 2.4 & 1.5 & 3.7 \\
\hline Offshore & 0.4 & 0.4 & -5.2 & -4.4 \\
\hline Std dev & 0.9 & 0.7 & 4.9 & 5.3 \\
\hline Net (west of $31.5^{\circ} \mathrm{W}$ ) & 3.8 & 14.6 & 3.7 & 22.1 \\
\hline Std dev & 2.1 & 2.6 & 5.1 & 5.3 \\
\hline \multicolumn{5}{|c|}{ (b) $11^{\circ} \mathrm{S}$ five sections } \\
\hline Boundary & 1.6 & 12.9 & 10.9 & 25.4 \\
\hline Std dev & 1.0 & 3.5 & 3.9 & 7.4 \\
\hline Offshore & -0.5 & 0.9 & -4.1 & -3.7 \\
\hline Std dev & 0.9 & 0.9 & 3.7 & 4.7 \\
\hline Net (west of $32.0^{\circ} \mathrm{W}$ ) & 1.1 & 13.8 & 6.8 & 21.7 \\
\hline Std dev & 1.5 & 2.8 & 1.3 & 4.1 \\
\hline
\end{tabular}

in the upper NADW layer (Fig. 6a) and a range of 12-39 Sv west of $33.5^{\circ} \mathrm{W}$. The mean southward DWBC transport between $\sigma_{1}=32.15 \mathrm{~kg} \mathrm{~m}^{-3}$ and $\sigma_{4}=45.90 \mathrm{~kg}$ $\mathrm{m}^{-3}$ (separating the lower NADW from the AABW water mass properties) west of about $33.5^{\circ} \mathrm{W}$ was 25.5 $\pm 8.3 \mathrm{~Sv}$ (Fig. 7a, Table 3a) for the nine sections. The largest portion, $15.3 \pm 5.4 \mathrm{~Sv}$, of the southward DWBC occurred in the upper NADW, with the middle NADW carrying $8.8 \pm 4.4 \mathrm{~Sv}$, and the lower NADW the smallest amount, just $1.4 \pm 2.2 \mathrm{~Sv}$. The section-net deep southward NADW transport, however, is reduced to $20.3 \pm 10.1 \mathrm{~Sv}$ because of northward offshore flows, particularly in the middle NADW layer, carrying $4.2 \pm$ 5.4 Sv. Besides the addition of the three new sections, the difference of our new mean DWBC transports of $25.5 \pm 8.3 \mathrm{~Sv}$ as compared with the earlier value of 31.7 $\pm 9.2 \mathrm{~Sv}$ of Schott et al. (2002) is because, in the earlier calculation, the mean was determined by averaging only over the southward flows along the boundary of the six available sections, whereas here the transport is determined from the mapped mean section.

\section{b. The $11^{\circ} \mathrm{S}$ circulation in the shipboard sections}

The five individual sections at $11^{\circ} \mathrm{S}$, while basically agreeing with the $5^{\circ} \mathrm{S}$ section regarding the flow structure in the upper layers, show much stronger offshore counterflows for the NADW layer than at $5^{\circ} \mathrm{S}$, in particular in the March 2000 and May 2003 surveys (Fig. $6 b)$. As the moored-current time series already sug- gested, several of the ship sections were taken at times of intensified deep southward currents near the boundary, thus sampling particular patterns of the deep variance.

\section{1) UPPER LIMB}

The mean flow structure (Fig. 7b) is similar to the one at $5^{\circ} \mathrm{S}$ (Fig. $7 \mathrm{a}$ ) with the NBUC already well developed, indicating that the bifurcation of the southern SEC is located well south of this section. The fivesection mean NBUC transport across the $11^{\circ} \mathrm{S}$ section, west of our section limit at $32^{\circ} \mathrm{W}$ and above $\sigma_{1}=32.15$ $\mathrm{kg} \mathrm{m}^{-3}$, is $25.4 \pm 7.4 \mathrm{~Sv}$ (Fig. 7b, Table 2b). The mean and all five individual sections at $11^{\circ} \mathrm{S}$ show southward flow just to the east of the lower NBUC (Figs. 6b, 7b), for which we determine a mean of $4.1 \pm 3.7 \mathrm{~Sv}$ in the third layer west of $32^{\circ} \mathrm{W}$ (Table $2 b$ ). It is consistent with the southward flow of $5.2 \pm 4.9 \mathrm{~Sv}$ observed at $5^{\circ} \mathrm{S}$ (Fig. $7 \mathrm{a})$, suggesting a continuous offshore recirculation branch in the $\sigma_{\theta}=26.8 \mathrm{~kg} \mathrm{~m}^{-3}$ to $\sigma_{1}=32.15 \mathrm{~kg} \mathrm{~m}^{-3}$ density range in that latitude band.

When integrated over the total extent of both ship sections, the upper-limb transports are nearly the same at $5^{\circ}$ and $11^{\circ} \mathrm{S}$, at $22.1 \pm 5.3 \mathrm{~Sv}$ and $21.7 \pm 4.1 \mathrm{~Sv}$, respectively. There is about a $3 \mathrm{~Sv}$ loss in the third layer and a corresponding gain in the top layer along the way, while the second layer with the strongest currents and largest transports is nearly continuous along the boundary at $5^{\circ}-11^{\circ} \mathrm{S}$ (Table $2 \mathrm{~b}$ ). These convergence/ divergence numbers are nonetheless all within the error bars of the section and layer averages.

\section{2) NADW}

Doing the calculation similarly as discussed above for $5^{\circ} \mathrm{S}$ yields a very large mean southward transport along the boundary from the five sections, of $35.5 \pm 14.7 \mathrm{~Sv}$ for the total of the three NADW layers (Fig. 6b, Table $3 b)$. However, there is also a large apparent northward recirculation immediately offshore from the southward current core, compensated partially again by some southward currents farther offshore, with the total offshore northward flow from the five-section mean amounting to $10.9 \pm 16.0 \mathrm{~Sv}$ (Table $3 \mathrm{~b}$ ). As shown by D04, the southward transport of deep water across this section is accomplished by migrating anticyclonic eddies with vanishing southward flow between eddy oc-

FIG. 6. Alongshore current distributions from the individual current velocity profiling surveys by ADCP/LADCP $\left(\mathrm{cm} \mathrm{s}^{-1}\right)$ off Brazil from (a) nine cruises along $\sim 5^{\circ} \mathrm{S}$ (positive is toward $349^{\circ} \mathrm{T}$ ) and (b) from five sections along $\sim 11^{\circ} \mathrm{S}$ (positive is toward $36^{\circ} \mathrm{T}$ ); for section locations see Fig. 1. Also marked are transports (Sv) in boxed NBUC (red dashed) and deep boundary (black dashed) areas. 

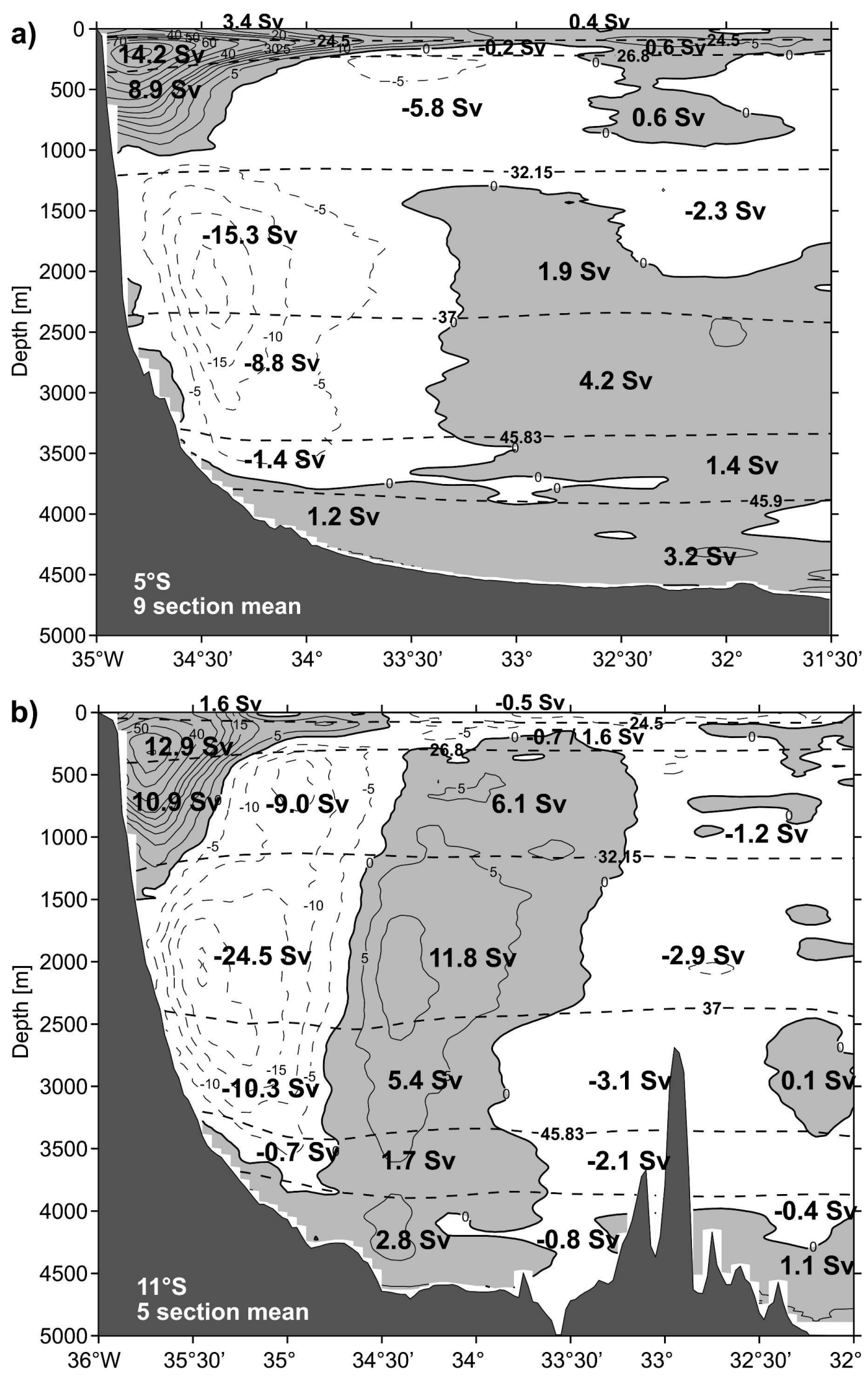
TABLE 3. Transports (Sv) of deep water masses from ship sections.

\begin{tabular}{|c|c|c|c|c|c|}
\hline $\begin{array}{l}\text { Water mass } \\
\text { Density layer }\end{array}$ & $\begin{array}{c}\text { Upper NADW } \\
32.15-37.00\end{array}$ & $\begin{array}{c}\text { Middle NADW } \\
37.00-45.83\end{array}$ & $\begin{array}{c}\text { Lower NADW } \\
45.83-45.90\end{array}$ & $\begin{array}{c}\text { Total NADW } \\
\text { total }\end{array}$ & $\begin{array}{c}\text { AABW } \\
>45.9\end{array}$ \\
\hline \multicolumn{6}{|c|}{ (a) $5^{\circ} \mathrm{S}$ nine sections } \\
\hline Boundary & -15.3 & -8.8 & -1.4 & -25.5 & 1.2 \\
\hline Std dev & 5.4 & 4.4 & 2.2 & 8.3 & 1.2 \\
\hline Offshore & -0.4 & 4.2 & 1.4 & 5.2 & 3.2 \\
\hline Std dev & 7.7 & 5.4 & 2.8 & 11.9 & 2.6 \\
\hline Net (west of $31.5^{\circ} \mathrm{W}$ ) & -15.7 & -4.6 & 0.0 & -20.3 & 4.4 \\
\hline Std dev & 7.5 & 5.1 & 2.9 & 10.1 & 3.0 \\
\hline \multicolumn{6}{|c|}{ (b) $11^{\circ} \mathrm{S}$ five sections } \\
\hline Boundary & -24.5 & -10.3 & -0.7 & -35.5 & 1.2 \\
\hline Std dev & 9.5 & 5.1 & 0.9 & 14.7 & 0.7 \\
\hline Offshore & 8.9 & 2.4 & -0.4 & 10.9 & 1.5 \\
\hline Std dev & 8.8 & 6.6 & 2.0 & 16.0 & 2.8 \\
\hline Net (west of $32.0^{\circ} \mathrm{W}$ ) & -15.6 & -7.9 & -1.1 & -24.6 & 2.7 \\
\hline Std dev & 4.5 & 2.3 & 1.9 & 5.0 & 2.9 \\
\hline
\end{tabular}

currences, such that averaging only over the nearboundary regime must lead to a rectified southward mean flow that is an unrealistic measure of DWBC transport.

Furthermore, there is a sampling problem due to how the ship section encounters the eddy situation. When integrating over the whole section while an eddy is at near maximum, there will be an overestimation of the mean southward NADW transport, while no transport will be measured when carrying out a section in between eddy occurrences. Indeed, the first four sections were taken at times of southward current maxima (Figs. $5 b, c)$ and the presence of intense deep northward offshore cores (Fig. 6b), which is in accordance with an anticyclonic eddy being cut by the shipboard section near its center. Thus, the net southward NADW transport through the entire $11^{\circ} \mathrm{S}$ section west of $32^{\circ} \mathrm{W}$ that amounts to $24.6 \pm 5.0 \mathrm{~Sv}$ overestimates the timeaverage southward NADW transport, even when integrating over the full extent of an eddy.

\section{c. The $A A B W$ layer}

In the bottom water layer, below $\sigma_{4}=45.90 \mathrm{~kg} \mathrm{~m}^{-3}$, eight of the nine sections at $5^{\circ} \mathrm{S}$ yielded northward net flow (1992 being the exception; Fig. 6a), but a well defined northward AABW boundary core is not iden- tified (Fig. 7a). The mean flow in the boundary region west of $33.5^{\circ} \mathrm{W}$ is northward at only $1.2 \pm 1.2 \mathrm{~Sv}$ and farther offshore it is $3.2 \pm 2.6 \mathrm{~Sv}$, yielding a total of 4.4 $\pm 3.0 \mathrm{~Sv}$ for the entire section, that is, west of $31.5^{\circ} \mathrm{W}$ (Table 3a). At $11^{\circ} \mathrm{S}$, the estimate for the five-section mean transport in the bottom layer is $2.7 \pm 2.9 \mathrm{~Sv}$ (Table $3 \mathrm{~b}$ ). While the lower value relative to the $5^{\circ} \mathrm{S}$ result is still within the error bars of both estimates, there may also be other explanations to which we will come back later.

\section{NBUC transport variability}

\section{a. Upper-layer transport time series at $11^{\circ} \mathrm{S}$}

Transport time series were calculated from the mapped 10-day low-passed alongshore currents with gaps filled from the EOFs analysis, as explained in section $2 \mathrm{~b}$. The mean section from the moored records (Fig. 8) shows general agreement of the boundary current structure with the five-section mean of the shipboard observations (Fig. 7b). Particularly interesting is the result that the current at station $\mathrm{K} 4$ at 500-m depth (Fig. 5a) was statistically significantly southward at 6.8 $\mathrm{cm} \mathrm{s}^{-1}$ with $1.6 \mathrm{~cm} \mathrm{~s}^{-1}$ for the mean error, based on a decorrelation time scale of about 30 days of that record. As already pointed out, there was also southward mean

$\leftarrow$

FIG. 7. (a) Mean alongshore ADCP/LADCP current distribution $\left(\mathrm{cm} \mathrm{s}^{-1}\right)$ based on the nine sections taken during 1990-2004 off Brazil at $5^{\circ} \mathrm{S}$ (Fig. 6a); (b) as in (a) but the mean from five sections taken during 2000-04 along approximately $11^{\circ} \mathrm{S}$ (Fig. $6 \mathrm{~b}$ ). Mean transport numbers $(\mathrm{Sv})$ are for the northward warm water flow along the boundary within three layers above the isopycnal surface $\sigma_{1}=32.15 \mathrm{~kg} \mathrm{~m}^{-3}$; and for the southward North Atlantic Deep Water (NADW) flow within three layers between this isopycnal and the isopycnal surface $\sigma_{4}=45.90 \mathrm{~kg} \mathrm{~m}^{-3}$ that marks the interface between NADW and Antarctic Bottom Water (AABW). Also marked are offshore recirculations within each of the layers where observed. 


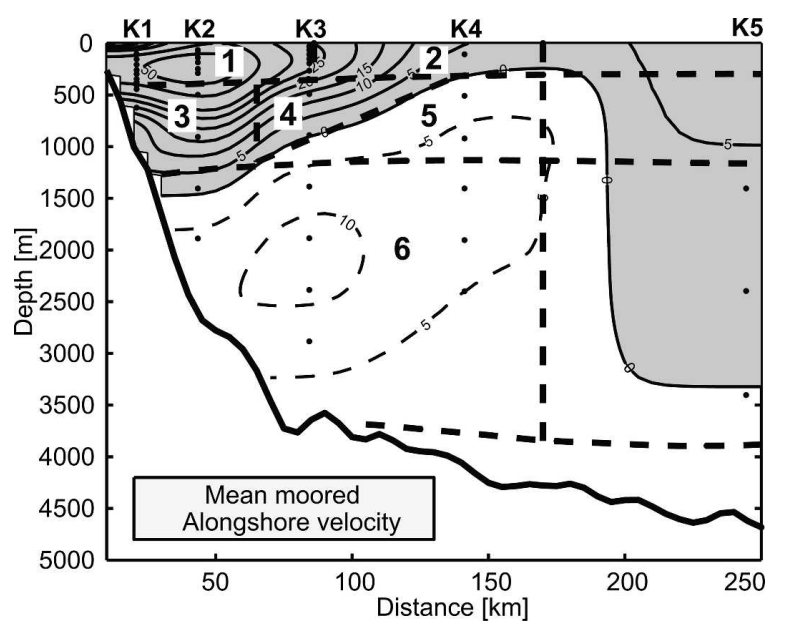

FIG. 8. Mean alongshore current distribution from moored records (locations marked by dots) and boxes 1-6 (heavy dashed) used for calculating transport time series.

flow observed offshore in that depth range in the ship observations along $5^{\circ} \mathrm{S}$ and $11^{\circ} \mathrm{S}$ (Figs. 7a,b), suggesting an offshore band of intermediate water recirculation in this latitude range.

From comparison with the mean ship section (Fig. 7a) we defined six boxes (marked in Fig. 8) for transport calculation. Boxes 1 and 2 are related to the upper NBUC, box 3 to the lower NBUC, while the triangular offshore box 4 was tailored to capture the offshore deep NBUC; box 5 encompasses the southward AAIW-layer offshore flow, and box 6 the NADW layer. Means and standard deviations of the transport time series for the individual boxes and the NBUC total (composite of boxes 1-4) are shown in Table 4a. As the EOF patterns

TABLE 4. Volume transports (Sv) from moored array at $11^{\circ} \mathrm{S}$ (for box boundaries see Fig. 8).

\begin{tabular}{lrrrrr}
\hline \hline & \multicolumn{2}{c}{ (a) 1613 days } & & \multicolumn{2}{c}{ (b) Five sections } \\
\cline { 2 - 3 } \cline { 6 - 7 } & Mean & Std dev & & Mean & Std dev \\
\hline Box 1 & 12.6 & 2.2 & & 13.1 & 2.9 \\
Box 2 & 2.7 & 1.5 & & 2.6 & 1.5 \\
Box 3 & 8.3 & 2.3 & & 10.0 & 1.8 \\
Box 4 & 2.1 & 1.6 & & 1.9 & 1.9 \\
NBUC 1-4 & 25.7 & 5.4 & & 27.5 & 7.2 \\
Box 5 & -2.4 & 3.3 & & -4.9 & 3.1 \\
NADW & -19.1 & 14.0 & & -31.3 & 20.2 \\
\hline
\end{tabular}

(c) Annual means

\begin{tabular}{lcc}
\hline Time period & NBUC & NADW \\
\hline Mar 2000-Mar 2001 & 25.7 & -14.4 \\
Mar 2001-Mar 2002 & 26.0 & -18.5 \\
Mar 2002-Mar 2003 & 26.7 & -24.3 \\
Mar 2003-Mar 2004 & 24.4 & -19.0 \\
\hline
\end{tabular}

of Fig. 9 suggest, variability of the NBUC should mainly be represented by the first mode and it indeed explains close to $60 \%$ of NBUC variance (Table 5a), while explaining $27 \%$ of total section variance (Fig. 9). The NBUC transport time series shows strong fluctuations, ranging from about 10 to $40 \mathrm{~Sv}$ (Fig. 10a). The NBUC transport mean of $25.7 \pm 5.4 \mathrm{~Sv}$ from the integral of boxes 1-4 (Table 4a) is slightly lower than the $27.5 \pm$ 7.2 Sv obtained when calculating the equivalent shipboard-section transports (Table 4b). The difference is mostly due to box 3 , the lower near-coastal boundary box. This might suggest that the shipboard NBUC mean is biased slightly high, but could also be due to the coarse instrumental coverage of that box by the moored array.

The ship section transports for the NBUC calculated from box areas 1-4 of the five individual surveys are inserted into Fig. 10a (heavy dots). The agreement is reasonably good, given the large variability, even at the time scale at which the surveys were done. The first two surveys happened close to moored transport minima and the third and last near transport maxima. Taken together with the other five ship section comparisons for the NADW-layer box 6 (Fig. 10b), the correlation between moored and shipboard transport estimates for the combined upper and lower layer box transports was determined to be 0.96 . This gave us some confidence into the realism of our method of filling gaps and interpolating of the moored data.

\section{b. Seasonal cycle}

The annual harmonic amplitude of the alongshore current fluctuations exceeds $5 \mathrm{~cm} \mathrm{~s}^{-1}$ in the NBUC, with maximum northward NBUC flow occurring in June-July (Fig. 11a). A weaker semiannual component has its northward maxima in January and July (Fig. $11 \mathrm{~b})$, that is, strengthening the boreal summer maximum. For the transport time series of Fig. 10a, the annual harmonic amplitude over the 4-yr-record length is $1.5 \mathrm{~Sv}$ with its northward maximum in May; the semiannual harmonic amplitude amounts to $1.7 \mathrm{~Sv}$ with maxima in January and July. Their superposition yields the main northward NBUC maximum in July and minimum in October-November (Fig. 12). However, the semiannual signal varied significantly during the four years, with maximum energy in 2001-02 (Fig. 13b). There can of course be some projection into this quasisemiannual energy from some large intraseasonal events in Fig. 10a. Still, the northward summer maximum is a consistent result among different segments of the NBUC transport time series. Just taking 90-day arithmetic means centered around the maximum and minimum time of the seasonal NBUC transport curve 

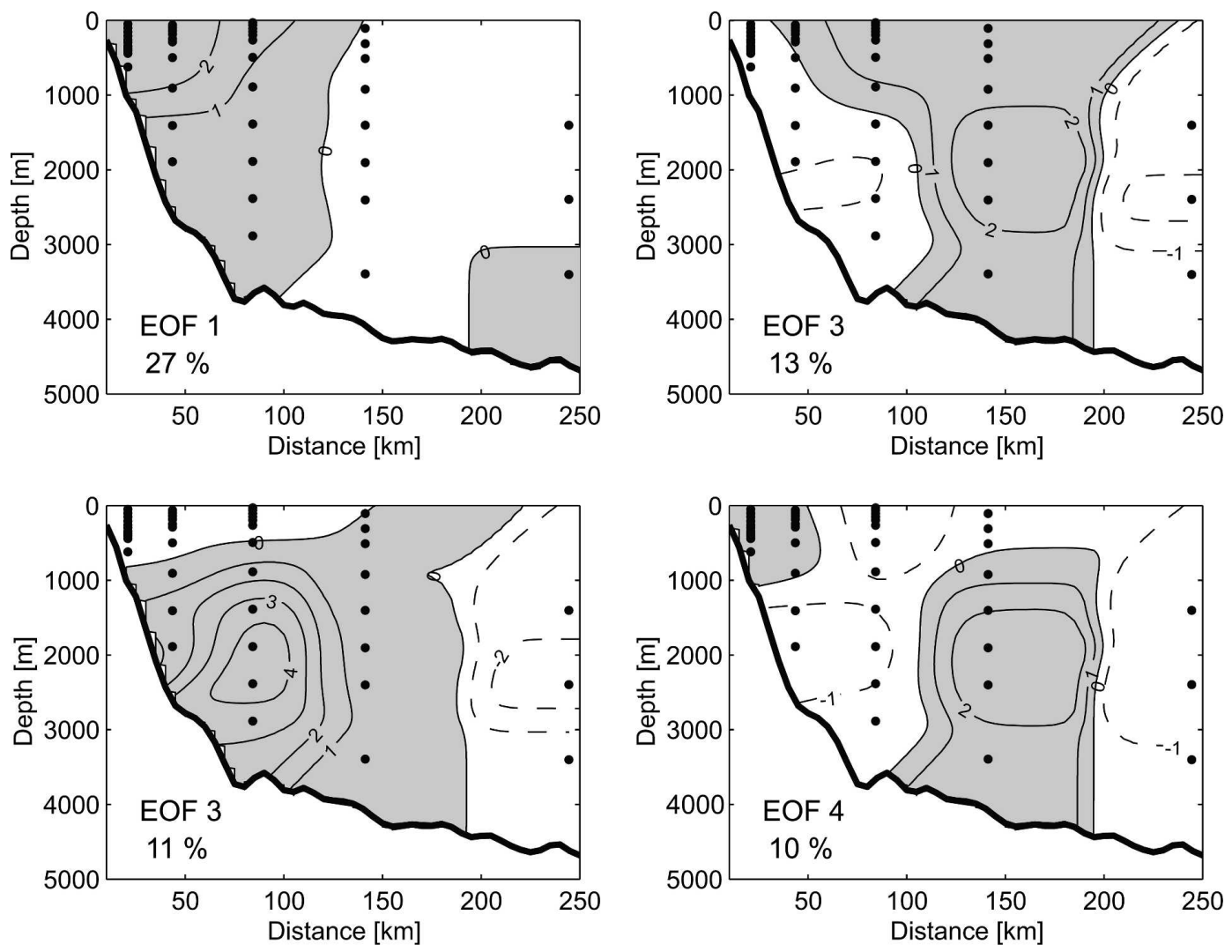

FIG. 9. EOFs 1-4 (contours: $\mathrm{cm} \mathrm{s}^{-1}$ ) determined from alongshore current components, including gappy records; see text for details; explained current-section variance given at lower left.

for all available years (dashed bars in Fig. 12) confirms that the harmonic analysis yields reasonable results, with the June-August mean about 4 Sv stronger northward than the October-December mean.

\section{c. Other variability}

At subseasonal time scales, the currents (Fig. 5a) and transports (Fig. 10a) of the NBUC domain show a dom-

TABLE 5. Variance of mapped NBUC and NADW transports at $11^{\circ} \mathrm{S}$ explained by individual and cumulative EOF time series.

\begin{tabular}{lrr}
\hline \hline Mode & \% of variance & \multicolumn{2}{c}{ \% of variance for cumulative EOF } \\
\hline & \multicolumn{2}{c}{ (a) NBUC (boxes 1-4) } \\
1 & 57 & 57 \\
2 & 14 & 75 \\
3 & 2 & 77 \\
4 & 10 & 83 \\
5 & 0 & 83 \\
& & (b) NADW (box 6) \\
1 & 0 & \\
2 & 6 & 0 \\
3 & 65 & 7 \\
4 & 4 & 70 \\
5 & 0 & 77 \\
\hline
\end{tabular}

inant fluctuation at about two months (Figs. 13a,b). Correlating the NBUC transport time series with all other current time series across the section from the first 685 days while the offshore mooring $\mathrm{K} 5$ was in place shows that this NBUC variability is restricted to the upper layer and uncorrelated with the variance in the NADW regime (Fig. 14a). This is confirmed by the pattern of EOF-1, which is restricted to the domain of the mean NBUC (Fig. 9). Interannual NBUC transport variability during the four years of moored records is actually fairly small, ranging only from $24.4-26.7 \mathrm{~Sv}$ (Table 4c), and not suggesting any longer-period trends (Fig. 10a).

\section{The NADW layer and transports at $11^{\circ} \mathrm{S}$ \\ a. The 60-70-day period and DWBC eddies}

The transport time series for the area of the nearboundary NADW flow, marked by box 6 in Fig. 8, shows fluctuations ranging from $60 \mathrm{~Sv}$ southward to 20 Sv northward (Fig. 10b), with a standard deviation of $\pm 14.0 \mathrm{~Sv}$, much larger than that of the NBUC (Table 4a). The ship section transports for box 6 (large dots in 

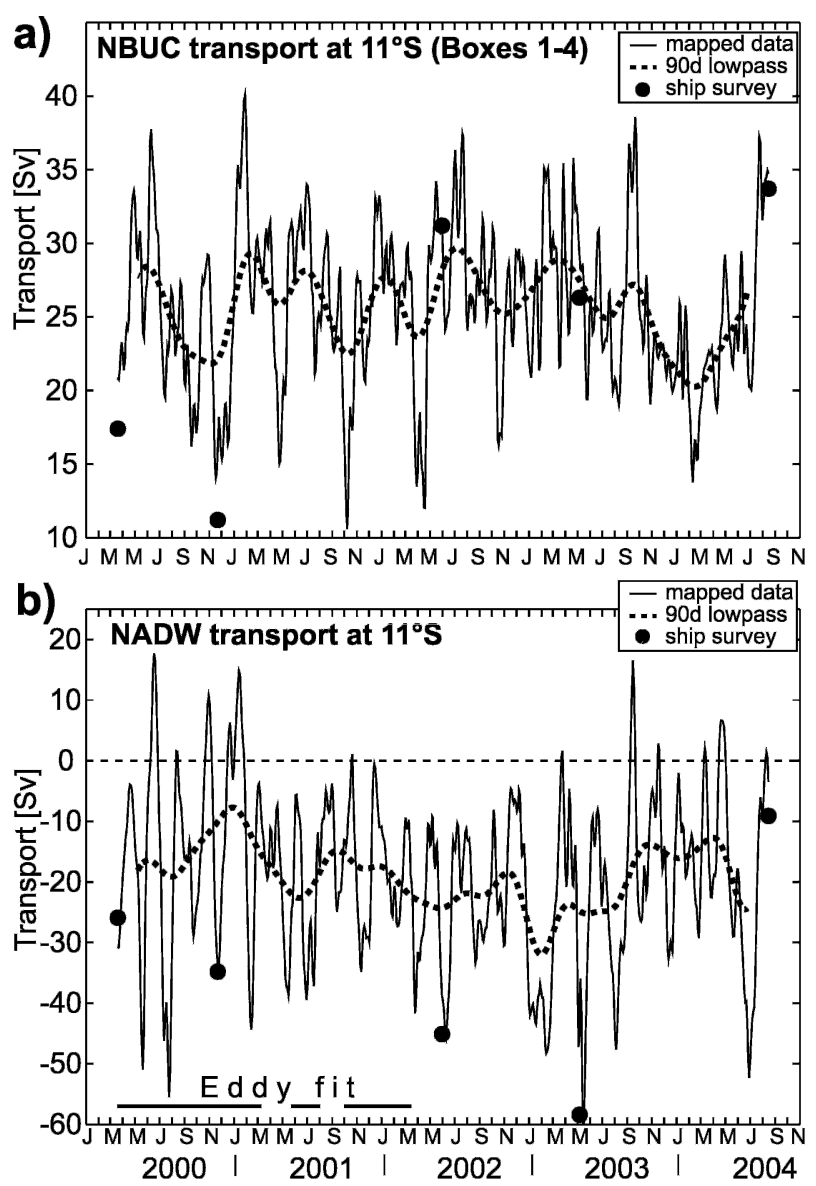

FIG. 10. Transport time series of (a) NBUC (boxes 1-4, Fig. 8) and (b) NADW (box 6) including ship-section transports of the five surveys for the same box boundaries (large dots); also shown are 90-day low-passed time series (dashed) and time periods where kinematic eddy model fit of Dengler et al. (2004) was applied to NADW transport variability (heavy bar).

Fig. 10b) fall right onto the moored values for each of the five surveys and, as discussed earlier, were measured at times of southward maxima during the first four cruises (Figs. 5b,c).

As already obvious from the selected times series (Fig. 5) and EKE distributions (Table 1), the variance has a pronounced maximum at the NADW level, which peaks in the period range of 60-70 days (Figs. 13a,c) and is much less pronounced at the upper levels except for the very near surface ADCP records (D04, their Fig. 2a). The mean NADW current is strongest near $2000 \mathrm{~m}$ at station $\mathrm{K} 3$, and there is mean offshore northward recirculation of $3-4 \mathrm{~cm} \mathrm{~s}^{-1}$ at 1400 and $2400 \mathrm{~m}$ at station K5 (Fig. 8, Table 1). Correlating the NADW transport time series of box 6 with all other current time series across the section from the first 685 days while the offshore mooring $\mathrm{K} 5$ was in place shows that the
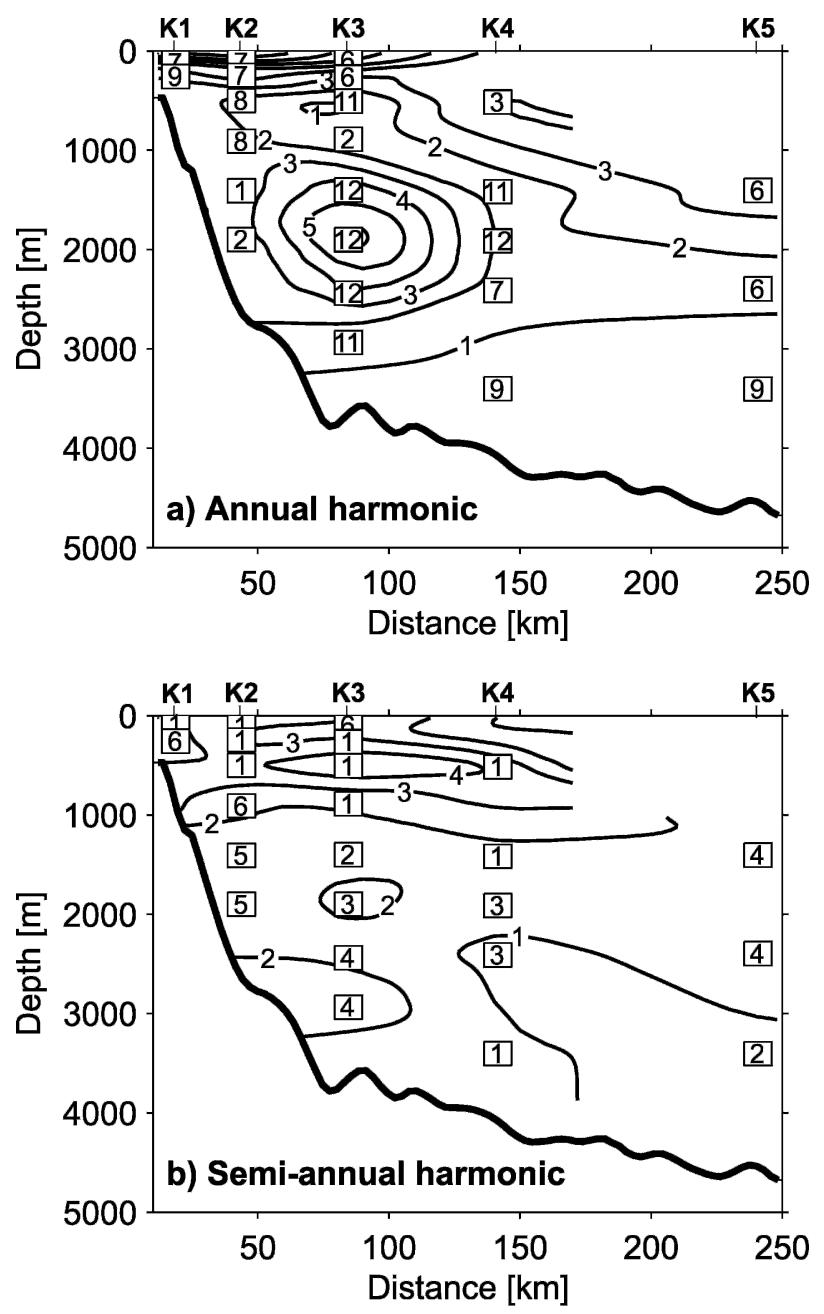

FIG. 11. (a) Distribution at $11^{\circ} \mathrm{S}$ of annual harmonic amplitudes (contours) and phases (numbers indicate month of northward maximum) from moored current time series; (b) as in (a) but for the semiannual harmonic.

DWBC variability is anticorrelated with the deep variability offshore at station K5 and is also uncorrelated with the flow above $1000 \mathrm{~m}$ (Fig. 14b).

All of these factors point to the presence of deep eddies: D04 recently showed, by fitting a kinematic eddy model to the joint data from stations $\mathrm{K} 1-\mathrm{K} 5$, that the deep variance maximum can be well explained by a sequence of anticyclones translating past the array site (their analysis period is marked in Fig. 10). From the sequence of nine fitted eddies during that first time period, D04 determined at a mean horizontal $e$-folding scale of $120 \pm 20 \mathrm{~km}$ and a southward eddy migration velocity of $3.8 \pm 0.9 \mathrm{~cm} \mathrm{~s}^{-1}$ past the array. The observed passage times and translation speed of the eddies imply that only negligible mean currents exist along the boundary. 


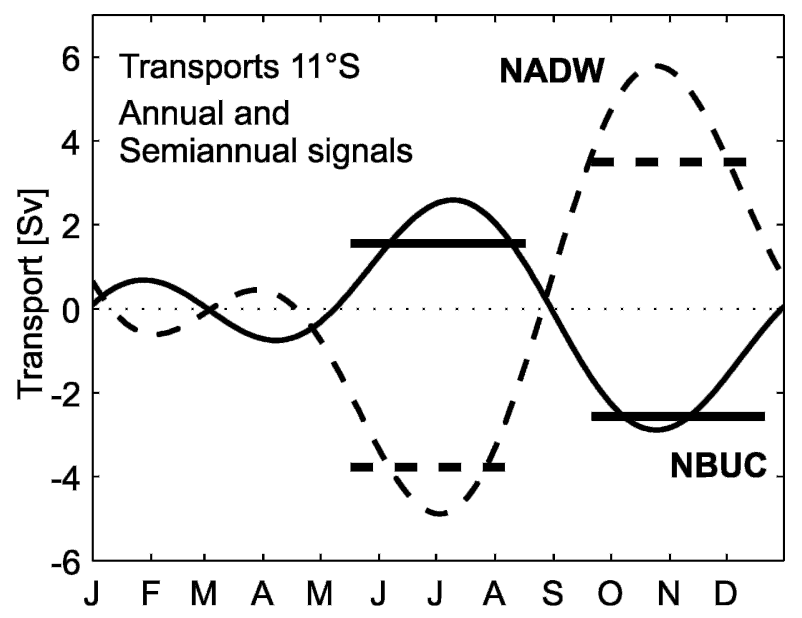

FIG. 12. Seasonal cycles (superposition of fitted annual plus semiannual harmonics; Sv) of transport time series of Fig. 10 for NBUC (sum of boxes 1-4: solid) and for NADW (box 6: dashed). Also shown are arithmetic means (horizontal bars) calculated from the transport time series for all available 90-day time periods centered at the times of the seasonal NBUC and NADW transport minima and maxima.

\section{b. Consequences for the mean southward NADW transport}

To address the sampling problem caused by the eddies translating past the moored array, we extended the eddy model fit of D04 to generate a time series of the "pure" eddy flow using the nine sets of individual eddy parameters, thus effectively bandpass filtering the moored records in time and space. The mean eddy flow field (Fig. 15) for the time period indicated in Fig. 10b yields a southward transport of $16.8 \mathrm{~Sv}$ for box 6 that compares well with the transport of $15.7 \mathrm{~Sv}$ calculated from the original velocity time series for box 6 and the same time period. In addition, the time-mean eddy flow field provides an estimate of the rectified northward transport contribution, yielding 1.9 Sv for a box extending offshore beyond $170 \mathrm{~km}$. This rectified northward transport accounts for slightly more than $10 \%$ of the time mean transport of box 6 and yields a total NADW transport of $15 \mathrm{~Sv}$ for the eddy fit time period. This NADW transport estimate is lower than the $18.5 \mathrm{~Sv}$ derived from eddy volumes by $\mathrm{D} 04$, as in their estimate topographic constraints were not considered and the outer eddy fringes were treated somewhat cruder.

Applying the above results to our deployment-long mean, under the assumption that the eddy model and scales determined for the first phase would be valid throughout, the box 6 transport of $19 \mathrm{~Sv}$ should be reduced by $2.1 \mathrm{~Sv}$ to yield a $16.9 \mathrm{~Sv}$ net southward NADW transport along the western boundary. This estimate is $3 \mathrm{~Sv}$ lower than the corresponding $5^{\circ} \mathrm{S}$ value,
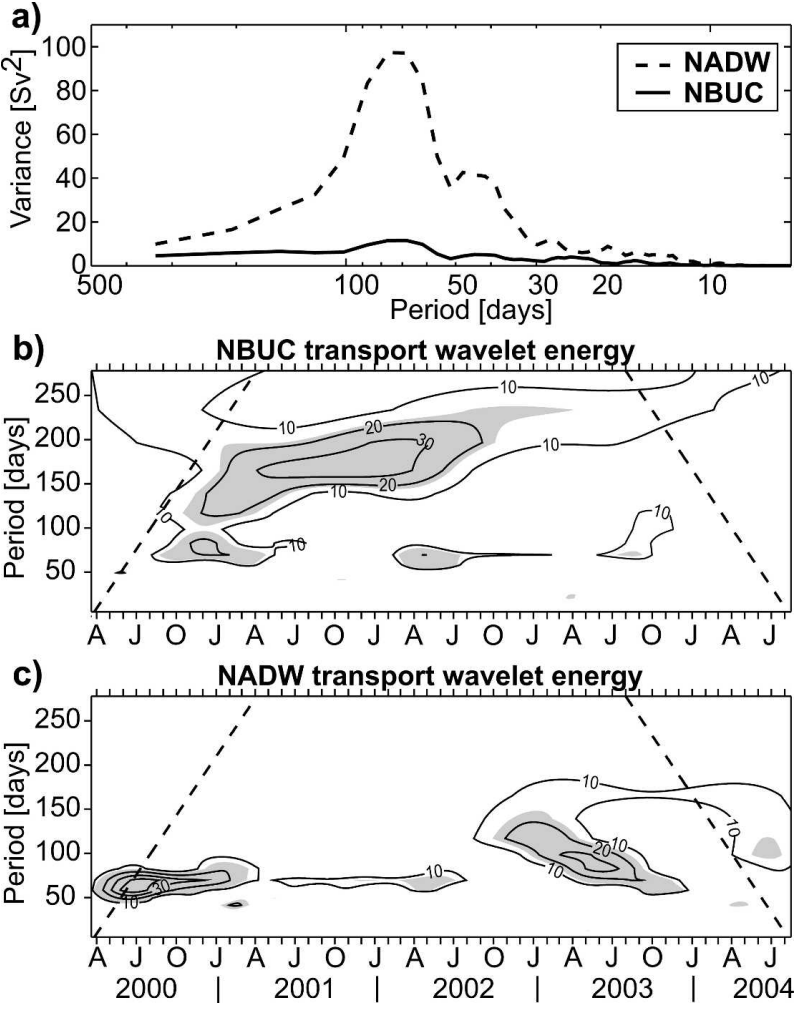

FIG. 13. (a) Variance-preserving energy spectra of NBUC and NADW transport time series of Fig. 10; (b) and (c) wavelet energy spectra of NBUC and NADW transport time series, normalized by their respective standard deviations.

probably caused by substantial interannual to decadal variability, discussed in the following section. However, other causes, such as aliasing or lateral outflow, cannot be excluded. In addition, it should be noted that transport calculations for box 6 used a fixed depthdistribution of the bounding isopycnals in time; thus the NADW transport contribution due to the bolus velocity of the migrating eddies was not considered.

\section{c. Seasonal and interannual variability in the NADW layer}

In the alongshore current distribution, the annual harmonic amplitude amounts also up to $6 \mathrm{~cm} \mathrm{~s}^{-1}$ in the near-boundary core, with maximum southward current in August-September (Fig. 11a), that is, close to the time of the annual northward NBUC maximum. The semiannual harmonic has small amplitudes and no stable phase among the instruments (Fig. 11b). The seasonal cycle of the transport in the NADW box (box 6, Fig. 8) ranges from southward values of $4.5 \mathrm{~Sv}$ in July to a maximum of $6 \mathrm{~Sv}$ northward in November (Fig. 12). However, values of the harmonic analysis are not stable and may change with longer time series. 

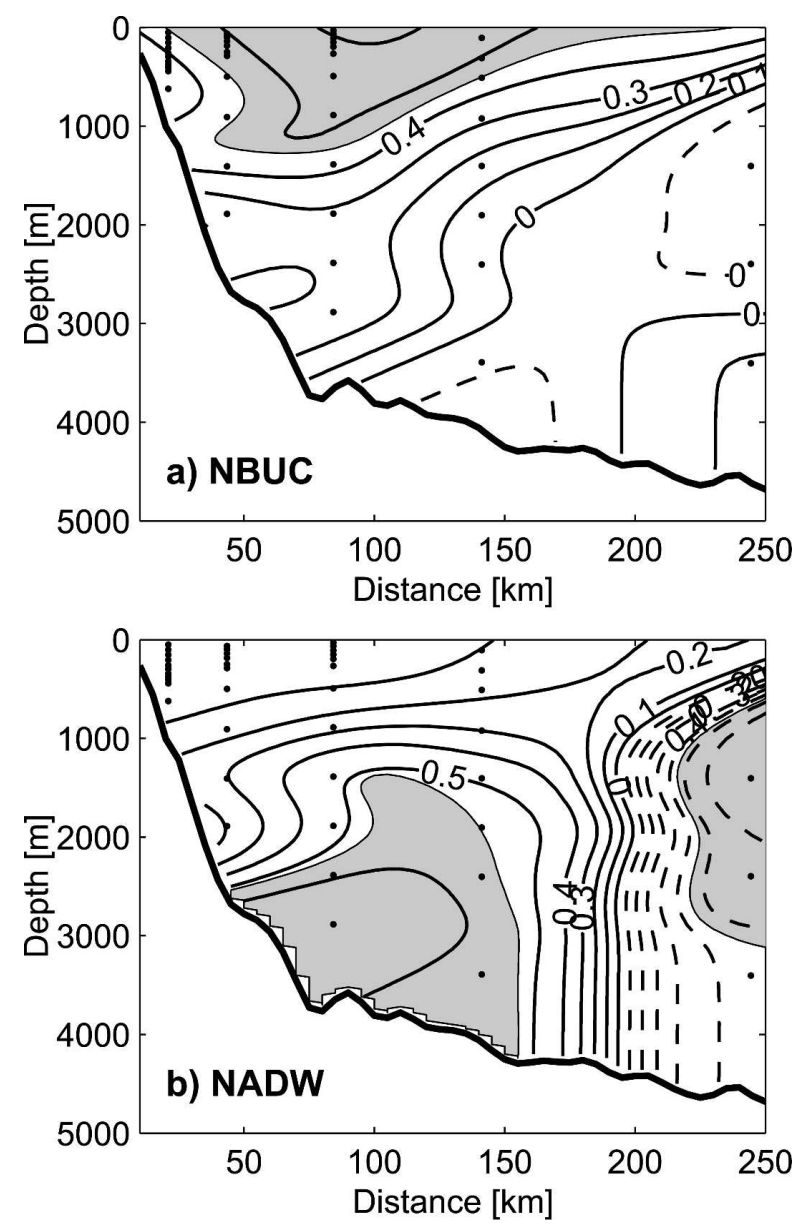

FIG. 14. Correlation of (a) NBUC transport time series (Fig. 10a) and of (b) NADW transport time series (Fig. 10b) with all alongshore current component records of the array (dots) for the first 685 days of the deployment while station $\mathrm{K} 5$ was in place.

At the 60-70-day period, there is a total of about 23 events visible in the NADW transport time series (Fig. $10 \mathrm{~b}$ ), of which half fall into the time period analyzed by D04. The NADW transport times series and its wavelet analysis (Fig. 13c) indicate that the variability at the 2-months period grows and wanes interannually, with maxima in 2000 and again in 2003, and lower amplitudes in 2001-02.

The consecutive annual transport averages in the NADW box 6 range from 14 to 24 Sv (Table 4c), but it follows from the D04 analysis and preceding sections that this does not mean that the NADW transport carried by the deep eddies changes interannually by that much; it could also be due to more or less energetic eddies, with larger or smaller swirl velocities.

\section{Discussion and conclusions}

In this section we will focus on three subjects: first, on the mean boundary current transports in the NBUC

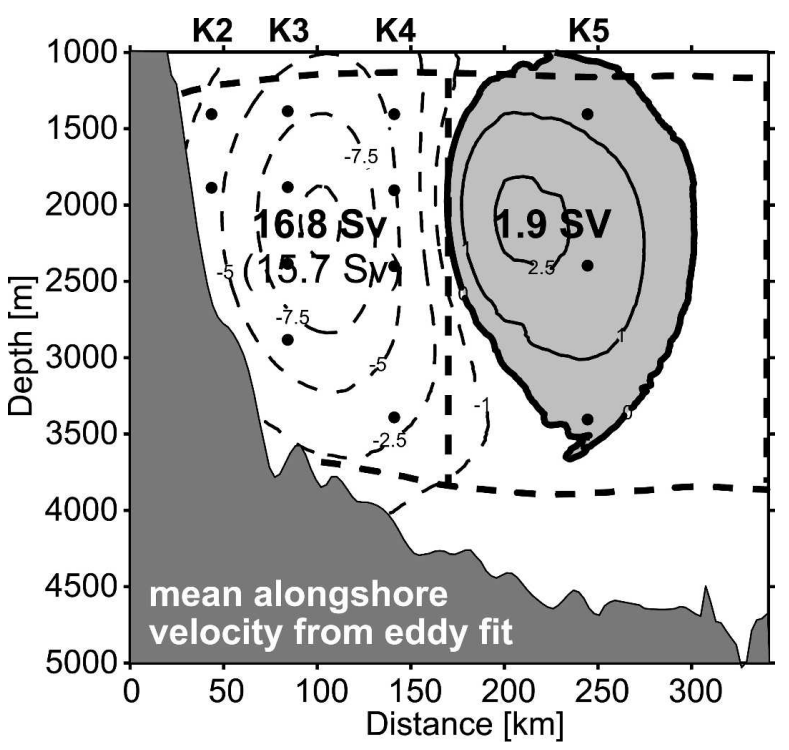

FIG. 15. Mean alongshore current distribution at $11^{\circ} \mathrm{S}$ section resulting from translation of deep eddies following the kinematic eddy model of D04; model fit is based on nine eddies during first deployment period (analysis period is marked in Fig. 10b). Transport numbers shown are for the eddy model within areas marked by dashed lines, and for box 6 transport from Fig. 10b, in parentheses.

and DWBC layers and how they might be connected at the larger scale; second, on the seasonal cycle of these flows; and third, on their interannual variability and its relation to the intraseasonal variability of about bimonthly period.

\section{a. Mean circulation: Connection of the boundary regime to the larger-scale flows}

\section{1) NBUC AND UPPER-LIMB CIRCULATION}

The NBUC is found here to originate farther south than $11^{\circ} \mathrm{S}$, its source being the SEC bifurcation (Stramma and Schott 1999), and its total transport at $11^{\circ} \mathrm{S}$ about equal to its transport at $5^{\circ} \mathrm{S}$. Different scenarios relate the NBUC at $5^{\circ}-11^{\circ} \mathrm{S}$ to the basinwide circulation, which we will discuss in this section.

In the 50-300-m depth range, the NBUC presumably plays an important role in the Atlantic STC. The driver of the STC is the poleward Ekman transport at the intersection between the Tropics and the subtropics in both hemispheres; that is, the STCs are "pulled" rather than "pushed" (by subduction; Schott et al. 2004). The strength of the southward Ekman transport at $10^{\circ} \mathrm{S}$ is determined at $11 \mathrm{~Sv}$ from National Centers for Environmental Prediction (NCEP) reanalysis wind stresses. The equatorward thermocline flow of the STC occurs in isopycnal range $\sigma_{\theta}=23.5-26.3 \mathrm{~kg} \mathrm{~m}^{-3}$, for which 
Zhang et al. (2003) diagnosed an interior equatorward thermocline flow across $6^{\circ} \mathrm{S}$ of $4 \mathrm{~Sv}$ and for which our observations in the boundary current at $5^{\circ} \mathrm{S}$ (Fig. 7a) yield $11 \mathrm{~Sv}$ in that same density range. The imbalance of this northward thermocline flow against the Ekman transport is mostly due to the Atlantic MOC (Schott et al. 2004). Further, as part of the horizontal Sverdrup circulation, there is a mean southward Sverdrup transport of $4 \mathrm{~Sv}$ across $11^{\circ} \mathrm{S}$ in the interior that would also require a compensating northward western boundary current. Hence, the role of the NBUC for the mean STC versus these other contributions is difficult to quantify, and dedicated model studies are needed, such as the particle trajectory study of Hazeleger and Drijfhout (2005, manuscript submitted to J. Geophys. Res.).

Below the STC level, substantial and persistent recirculation was observed at $5^{\circ}-11^{\circ} \mathrm{S}$ offshore from the NBUC, (Figs. 7 and 5a), amounting to about $5 \mathrm{~Sv}$ and reaching down to NADW densities. Where does this flow originate? Just to the northwest of the $5^{\circ} \mathrm{S}$ section, there is strong westward flow across the $35^{\circ} \mathrm{W}$ section (Fig. 1) near the boundary (Fig. 16a), and eastward flow by two undercurrents: about $3 \mathrm{~Sv}$ are transported by the South Equatorial Undercurrent (SEUC) at 150-400-mdepth and in latitude range $2.5^{\circ}-4^{\circ} \mathrm{S}$, and $6 \mathrm{~Sv}$ by the Southern Intermediate Countercurrent (SICC) at $1.5^{\circ}-$ $3.5^{\circ} \mathrm{S}$, reaching from 500-1200-m depth (Schott et al. 2003). For both these currents, no evidence of a southward deflection has been reported so far.

The NBUC grows from 27 to $32 \mathrm{~Sv}$ when turning around the northeastern tip of Brazil (Figs. 7a and 16a), which is partly due to the top layer that increases in transport from 3.7 to $6.6 \mathrm{~Sv}$ by shallow SEC inflow north of $5^{\circ} \mathrm{S}$, and partly to the third layer, which transports $8.9 \mathrm{~Sv}$ across $5^{\circ} \mathrm{S}$ but $11.2 \mathrm{~Sv}$ flow westward across $35^{\circ} \mathrm{W}$ as the lower NBC. The second layer, in density range $\sigma_{\theta}=24.5-26.8 \mathrm{~kg} \mathrm{~m}^{-3}$, transports the same amount of about $14 \mathrm{~Sv}$ through both sections, $5^{\circ} \mathrm{S}$ and $35^{\circ} \mathrm{W}$ (Fig. 1), from where it continues toward the equator and the retroflection zone (Schott et al. 1998).

Assuming first that none of the SEUC and SICC waters are turning southward would require an inflow from the east of about $8 \mathrm{~Sv}$ to close the layer budget if no significant diapycnal transfer takes place. From float trajectories at the 800-m level, an inflow from the east as part of the deep SEC has indeed been derived (Boebel et al. 1999, their Fig. 4; Schmid et al. 2001, their Fig. 11), which gets deflected southward before reaching the Brazil coast and thus forms an offshore counterflow to the deep NBUC. These trajectories thus support inflow from the east that supplies the offshore counterflow to the NBUC, which therefore is not an NBUC recirculation. We carried out three meridional sections along $28^{\circ} \mathrm{W}$, and there is, indeed, westward flow across $28^{\circ} \mathrm{W}$ just south of the SEUC (Fig. 16b), but this inflow is weak, transporting less than $5 \mathrm{~Sv}$.

Another possibility would be a retroflection of the deep NBUC just north of the northeastern tip of Brazil, to supply the southward offshore flow across $5^{\circ} \mathrm{S}$, as suggested in the high-resolution $\left(1 / 12^{\circ}\right)$ MICOM model simulation (Z. Garaffo 2004, personal communication). NBUC recirculation was also deduced in the steric height calculation for the 800-dbar level of Reid (1989; his Fig. 17), which shows a narrow cell off Brazil with southward offshore flow; that is, the counterflow is not supplied by the SEC but by recirculation from the NBUC. There are two options in this possibility. It is not altogether impossible, though unlikely, that this retroflection occurs before the NBUC even reaches the $35^{\circ} \mathrm{W}$ section (Fig. 1).

The other option would be that part of the SICC and SEUC flows do indeed turn south, but the SEUC transport increases from $35^{\circ}$ to $28^{\circ} \mathrm{W}$ and the SICC stays about constant (Fig. 16a). A cautionary note has to be applied here regarding the near-equatorial transports of Fig. 16b. While the seasonal bias in the 13-section coverage at $35^{\circ} \mathrm{W}$ is small and does not seem to significantly affect the mean transport values given in Fig. 16a (see also Schott et al. 2003), the three sections at $28^{\circ} \mathrm{W}$ (Fig. 16b) were acquired during May and August (inset, Fig. 1). By analyzing the 13 sections at $35^{\circ} \mathrm{W}$ and a high-resolution numerical model, Brandt and Eden (2005) found a strong seasonal cycle with amplitudes of about $10 \mathrm{~cm} \mathrm{~s}^{-1}$ in the depth range of the intermediate currents along the equator that could lead to larger EIC, SICC, and NICC transport values during MayAugust relative to an annual mean.

Another question is the fate of the offshore southward flow in the $5^{\circ}-11^{\circ} \mathrm{S}$ latitude range (Fig. 7), when approaching the SEC bifurcation. It is unclear whether it turns offshore or merges back into the SEC and/or lower NBUC. There is an eastward current below 200 $\mathrm{m}$ at $9^{\circ}-11^{\circ} \mathrm{S}$ across the $28^{\circ} \mathrm{W}$ section (Fig. 16b), in the region typically associated with the South Equatorial Countercurrent (SECC; Stramma and Schott 1999) that might be supplied by this southward counterflow.

\section{2) NADW LAYER}

The ship surveys at both repeat sections found the NADW transports near the boundary to be quite variable, with deep near-boundary currents sometimes even reversed to northward, quite different from the earlier DWBC observations at $44^{\circ} \mathrm{W}$ just north of the equator (Fischer and Schott 1997), where the DWBC flow at the boundary never reversed direction. The mean DWBC transport at $5^{\circ} \mathrm{S}$, based on nine ship sec- 

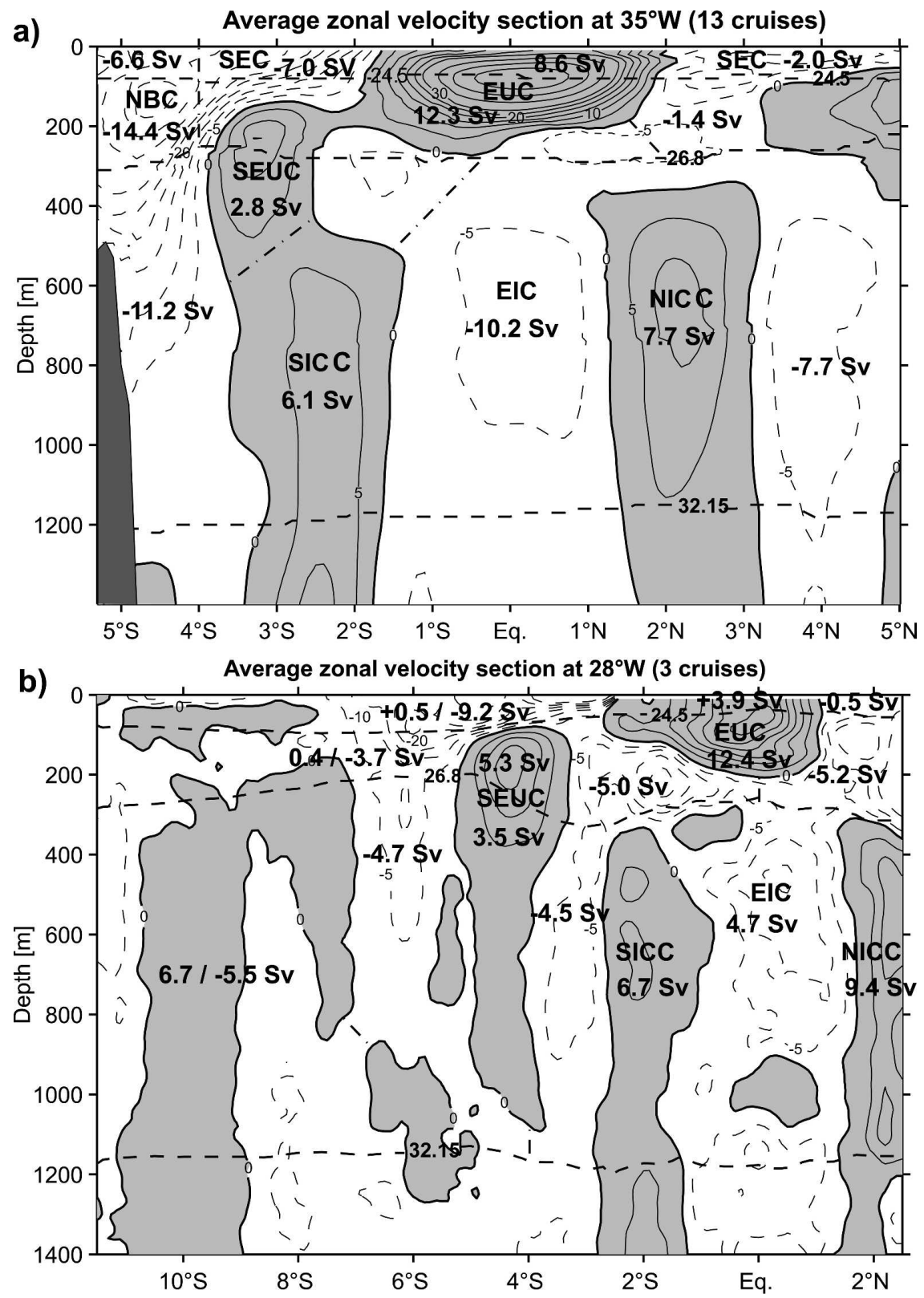

FIG. 16. (a) Zonal-mean currents (eastward shaded) and transports (Sv) across $35^{\circ} \mathrm{W}$ section, above $\sigma_{1}=32.15 \mathrm{~kg} \mathrm{~m}^{-3}$ isopycnal surface, based on 13 shipboard ADCP/LADCP sections (after Schott et al. 2003); (b) as in (a) but for mean of three sections along $28^{\circ} \mathrm{W}$ (section locations, see Fig. 1). Marked current cores are NBC $=$ North Brazil Current, SEC $=$ South Equatorial Current, EUC = Equatorial Undercurrent, SEUC $=$ South Equatorial Undercurrent, EIC = Equatorial Intermediate Current, and SICC and NICC $=$ Southern and Northern Intermediate Countercurrents; see text for details.

tions, was determined to be $25.5 \pm 8.3 \mathrm{~Sv}$, and offshore of it a mean northward flow of some $5 \mathrm{~Sv}$ appears to exist, yielding a section-net NADW transport of $20.3 \pm$ $10.1 \mathrm{~Sv}$. Nevertheless, a mean DWBC exists at $5^{\circ} \mathrm{S}$, while the situation is quite different at $11^{\circ} \mathrm{S}$, because the DWBC dissolves into a sequence of deep eddies between both latitudes (D04). Therefore, calculating the mean flow over the "DWBC" core at $11^{\circ} \mathrm{S}$ just yields a rectification of the swirl velocities of these eddies. Using the eddy model of D04, this rectified transport contribution was determined to be slightly more than $10 \%$ of the mean southward transport close to the 
western boundary, reducing the net average southward NADW transport to $17 \mathrm{~Sv}$ at $11^{\circ} \mathrm{S}$ (Fig. 15). Considering the large interannual variability of the transport time series at $11^{\circ} \mathrm{S}$, which ranged from 14 to $24 \mathrm{~Sv}$ (Table 4c), this result is considered to not be different from the $5^{\circ} \mathrm{S}$ section mean.

The water mass difference between the nearboundary and offshore branches at $5^{\circ}$ and $11^{\circ} \mathrm{S}$ underscores the different composition of the offshore NADW counterflows at both latitudes. While at $11^{\circ} \mathrm{S}$, the water masses in the nearshore and offshore eddy branch are nearly identical, being part of the same eddy (D04) there is a distinctive difference between the southward and northward NADW layer flows at $5^{\circ} \mathrm{S}$, but the later fate of this northward offshore flow across $5^{\circ} \mathrm{S}$ is not known.

When comparing the NADW arriving at the crossequatorial $35^{\circ} \mathrm{W}$ section of Schott et al. (2003) with the $5^{\circ} \mathrm{S}$ section, a drastic decrease of the lower NADW transport is found. It transports $7 \mathrm{~Sv}$ eastward across $35^{\circ} \mathrm{W}$ in its two near-boundary cores, while only $1.5 \mathrm{~Sv}$ are transported in the DWBC across $5^{\circ} \mathrm{S}$. The indications of water mass transformation become even more drastic if we compare the net layer flows across $35^{\circ} \mathrm{W}$ with the net through the $5^{\circ} \mathrm{S}$ section (west of $31.5^{\circ} \mathrm{W}$ ). At $35^{\circ} \mathrm{W}$, a net transport of $22 \mathrm{~Sv}$ of middle and lower NADW flows eastward between densities $\sigma_{2}=37.00 \mathrm{~kg}$ $\mathrm{m}^{-3}$ and $\sigma_{4}=45.90 \mathrm{~kg} \mathrm{~m}^{-3}$, but only $3 \mathrm{~Sv}$ of upper NADW (Schott et al. 2003). By contrast, the net southward flow in the middle and lower density layers across our $5^{\circ} \mathrm{S}$ section is only $5 \mathrm{~Sv}$, but in the upper NADW layer it is $15 \mathrm{~Sv}$ (Table 3a). This NADW composition is similar at the $11^{\circ} \mathrm{S}$ section (Table $3 \mathrm{~b}$ ).

This near-equatorial diapycnal water mass transformation into lighter density classes of about $10 \mathrm{~Sv}$ was also found in the inverse analysis of Lux et al. (2001) for layer transports across $4.5^{\circ} \mathrm{S}$ and $7.5^{\circ} \mathrm{N}$. It is one of the major oceanographic questions remaining today, which may involve circuitous zonal routes into the interior of the basin and interaction with the topography of the Mid-Atlantic Ridge.

\section{3) AABW}

The transport of $\mathrm{AABW}$ arriving in the equatorial zone across $5^{\circ} \mathrm{S}$ was calculated in our study to be $4.4 \pm$ $3.0 \mathrm{~Sv}$, in agreement with other previous results (Rhein et al. 1998; Lux et al. 2001; Ganachaud 2003). At $11^{\circ} \mathrm{S}$ the value was lower at $2.7 \pm 2.9 \mathrm{~Sv}$. While this difference is still within the error bars of both estimates, there are also plausible reasons why the AABW result at $11^{\circ} \mathrm{S}$ might be low. On the one hand, we experienced southward biasing of the mean by the NADW eddies at $11^{\circ} \mathrm{S}$, which might also extend into the AABW layer.
On the other hand, results of inverse studies indicate that the AABW flow does not appear to be well concentrated along the boundary at $5^{\circ}-10^{\circ} \mathrm{S}$, yielding significant offshore reversals in the different studies beyond the extent of our section (e.g., Lux et al. 2001; Ganachaud 2003; Lumpkin and Speer 2003). Last, because of the 5000-m depth limitation of our LADCP pressure case, the deeper offshore parts of the AABW flow could not be observed.

\section{b. Seasonal cycle}

Our analysis found a seasonal cycle of the NBUC of an about $4 \mathrm{~Sv}$ range with a strong semiannual harmonic (Fig. 12), leading to a northward maximum in July and a minimum in October-November. The semiannual energy varied significantly during the observational period (Fig. 13b), suggesting that the total seasonal curve may differ for other time periods. However, taking arithmetic means over three months at the individual years around the times of the maximum and minimum, respectively, confirmed the seasonality of the NBUC transport (solid line in Fig. 12). For the $5^{\circ} \mathrm{S}$ section it is probably inadequate to extract a seasonal cycle from nine transport sections, but the result is a northward maximum in June-July, in agreement with the moored transport values at $11^{\circ} \mathrm{S}$.

One possible interpretation for the seasonal variability is that there is a seasonal migration of the latitude of the SEC inflow into the western boundary regime. Another source of a seasonal boundary transport variability is the interior Sverdrup transport, and previous studies in the northern Tropics (Johns et al. 1998) and subtropics (Lee et al. 1996) have shown that quasistationary response at the annual time scale can indeed occur in latitudes as studied here.

Based on the NCEP reanalysis stresses, the Sverdrup transport has a southward maximum in July and a broad minimum of during November-May with an annual range of $12 \mathrm{~Sv}$. When calculated from the QuikSCAT (quick scatterometer) data, the southward maximum also occurs in July but the annual range is lower, about $8 \mathrm{~Sv}$. The agreement of the southward Sverdrup transport maximum and northward NBUC maximum (Fig. 12) suggests that the NBUC seasonal cycle may be affected by a response to the interior Sverdrup forcing, but the seasonal curves of NBUC and Sverdrup transport differ, even when the Sverdrup transport is taken for the western basin alone. Hence, further study will be required to investigate the detailed Rossby wave response in different parts of the basin to wind stress curl forcing at $10^{\circ}-12^{\circ} \mathrm{S}$ and how much of observed NBUC variance it may explain.

For the transport time series in the NADW box 6 
(Fig. 8), the seasonal cycle derived is almost similar but out of phase with the NBUC cycle. A possible interpretation would be a response to interior wind forcing, occurring as a first-mode Rossby wave. While D04 had concluded that the DWBC eddies migrate along the boundary without needing any mean background flow transporting them, there might be this seasonal cycle superimposed, causing a seasonal Doppler effect on eddy passage times.

\section{c. Intraseasonal and interannual variability}

In the NBUC domain as well as in the NADW domain, the intraseasonal variability is dominated by fluctuations a bit longer than two months. The energy in this period band is much higher at the NADW level than in the upper layers (Fig. 13a). The NBUC transports and the NADW transports are uncorrelated (Fig. 14). It therefore appears that there are two different physical processes at work in the upper and lower layers. As discussed, the cause for intraseasonal variance in the NADW domain has been determined by D04 to be internally generated, by upstream instability of the DWBC. For the upper layers it could be wind generated since intraseasonal forcing of numerical models with daily winds yields energy in this band (Z. Garaffo 2004, personal communication). This variability is presently being studied and results will be reported elsewhere.

As mentioned at the beginning, the main objective for carrying out the moored array transport observations was to investigate whether or not there is interannual and longer-term variability of the NBUC that might be related to STC variability and potentially provide an index of it. The result so far was, however, that the variability among annual means of our 4-yr NBUC time series was small, with no detectable trend. The implication is that STC changes in the Atlantic might be small, relative to those in the Pacific (McPhaden and Zhang 2004).

For the NADW regime, D04 determined that transport calculations from near-boundary deep current observations alone do not provide direct evidence on NADW transport variability because it would just be a rectification of swirl velocities caused by the migrating deep eddies. While one station (K5: Fig. 5c and Fig. 8) was located in the offshore counterflow during the first phase of the program, allowing D04 to fit their kinematic eddy model, this station was absent during the second half of the experiment, no longer allowing conclusive eddy fits from the in-phase part of the array alone. Annual means differ much more for the NADW transport box than for the NBUC (Table 4c), ranging from 14 to $24 \mathrm{~Sv}$. The intraseasonal energy changes as well (Fig. 13c), but these interannual differences are not clearly associated with box-6 transport changes.

The instability process that causes the DWBC to break up into eddies somewhere near $8^{\circ} \mathrm{S}$ (D04) appears to occur (in models) above a certain velocity or transport threshold at that latitude, so that at times of weaker flow the NADW transport near $11^{\circ} \mathrm{S}$ might be performed by a laminar DWBC rather than eddies. Conversely, at times of stronger flows more eddies per year might be shed. It is therefore unclear at present to what degree this near boundary transport variability reflects real changes associated with NADW transport variability.

Acknowledgments. We thank captains and crews of the Research Vessels Meteor and Sonne, as well as U. Papenburg and M. Müller for technical assistance during the shipboard and moored station work. We are particularly thankful for the help of the Brazilian Navy and of our colleagues M. Araujo and O. de Aragao (University of Pernambuco, Recife) in retrieving lost gear off Brazil. We gratefully acknowledge the support by Dr. R. Molinari and his group of NOAA/AOML (Miami) as well as officers and crew of NOAA ship Ron Brown in exchanging the moored array in February 2002. We further acknowledge the competent help of J. Schafstall in the analysis work. Constructive comments by two anonymous reviewers helped to improve the paper. This study was supported by the German Bundesministerium für Bildung, Wissenschaft and Forschung (BMBF) as part of the German CLIVAR/marin program (Contract 03F0246A) and by support of Sonne cruises; and by Deutsche Forschungsgemeinschaft (DFG) through funding of Meteor cruises.

\section{REFERENCES}

Boebel, O., C. Schmid, and W. Zenk, 1999: Kinematic elements of Antarctic Intermediate Water in the western South Atlantic. Deep-Sea Res., 46B, 355-392.

Brandt, P., and C. Eden, 2005: Annual cycle and interannual variability of the mid-depth tropical Atlantic Ocean. Deep-Sea Res., 52A, 199-219.

Dengler, M., F. A. Schott, C. Eden, P. Brandt, J. Fischer, and R. Zantopp, 2004: Break-up of the Atlantic deep western boundary current into eddies at $8^{\circ} \mathrm{S}$. Nature, 432, 1018-1020.

Fischer, J., and F. Schott, 1997: Seasonal transport variability of the deep western boundary current in the Atlantic. J. Geophys. Res., 102 (C13), 27 751-27 769.

— , P. Brandt, M. Dengler, M. Müller, and D. Symonds, 2003: Surveying the upper ocean with the ocean surveyor: A new phased array Doppler current profiler. J. Atmos. Oceanic Technol., 20, 742-751.

Ganachaud, A., 2003: Large-scale mass transports, water mass formation and diffusivities estimated from World Ocean Cir- 
culation Experiment (WOCE) hydrographic data. J. Geophys. Res., 108, 3213, doi:10.1029/2002JC001565.

Johns, W. E., T. N. Lee, R. C. Beardsley, J. Candela, R. Limeburger, and B. Castro, 1998: Annual cycle and variability of the North Brazil Current. J. Phys. Oceanogr., 28, 103-128.

Lee, T. N., W. E. Johns, R. J. Zantopp, and E. R. Fillenbaum, 1996: Moored observations of western boundary current variability and thermohaline circulation at $26.5^{\circ} \mathrm{N}$ in the subtropical North Atlantic. J. Phys. Oceanogr., 26, 962-983.

Lumpkin, R., and K. Speer, 2003: Large-scale vertical and horizontal circulation in the North Atlantic Ocean. J. Phys. Oceanogr., 33, 1902-1920.

Lux, M., H. Mercier, and M. Arhan, 2001: Interhemispheric exchanges of mass and heat in the Atlantic Ocean in JanuaryMarch 1993. Deep-Sea Res., 48A, 605-638.

Malanotte-Rizzoli, P., K. Hedstrom, H. Arango, and D. B. Haidvogel, 2000: Water mass pathways between the subtropical and tropical ocean in a climatological simulation of the North Atlantic Ocean circulation. Dyn. Atmos. Oceans, 32, 331-371.

Mayer, D. A., R. L. Molinari, and J. F. Fiesta, 1998: The mean and annual cycle of upper layer temperature fields in relation to Sverdrup dynamics within the gyres of the Atlantic Ocean. $J$. Geophys. Res., 103, 18 545-18 566.

McPhaden, M., and D. Zhang, 2004: Pacific Ocean circulation rebounds. Geophys. Res. Lett., 31, L18301, doi:10.1029/ 2004 GL020727.

Reid, J. L., 1989: On the total geostrophic circulation of the South Atlantic Ocean: Flow patterns, tracers, and transports. Progress in Oceanography, Vol. 23, Pergamon, 149-244.

Rhein, M., and L. Stramma, 2005: Seasonal variability in the Deep Western Boundary Current around the eastern tip of Brazil. Deep-Sea Res., 52A, 1414-1428.

_ - _ , and U. Send, 1995: The Atlantic Deep Western Boundary Current: Water masses and transports near the equator. J. Geophys. Res., 100 (C2), 2441-2457.

, - _ , and G. Krahmann, 1998: The spreading of Antarctic Bottom Water in the tropical Atlantic. Deep-Sea Res., 45, 507-527.
Schmid, C., R. L. Molinari, and S. L. Garzoli, 2001: New observations of the intermediate depth circulation in the tropical Atlantic. J. Mar. Res., 59, 281-312.

Schott, F., J. Fischer, and L. Stramma, 1998: Transports and pathways of the upper-layer circulation in the western tropical Atlantic. J. Phys. Oceanogr., 28, 1904-1928.

_, P. Brandt, M. Hamann, J. Fischer, and L. Stramma, 2002: The boundary flow off Brazil at $5^{\circ}-10^{\circ} \mathrm{S}$. Geophys. Res. Lett., 29, 1840, doi:10.1029/2002GL014786.

_ , and Coauthors, 2003: The zonal currents and transports at $35^{\circ} \mathrm{W}$ in the tropical Atlantic. Geophys. Res. Lett., 30, 1349 , doi:10.1029/2002GL016849.

_ J. P. McCreary, and G. C. Johnson, 2004: Shallow overturning circulations of the tropical-subtropical oceans. Earth Climate: The Ocean-Atmosphere Interaction, C. Wang, S.-P. Xie, and J. A. Carton, Eds., Geophys. Monogr., Amer. Geophys. Union, 261-304.

Snowden, D. P., and R. L. Molinari, 2003: Subtropical cells in the Atlantic Ocean: An observational summary. Interhemispheric Water Exchange in the Atlantic Ocean, G. Goni and P. Malanotte-Rizzoli, Eds., Vol. 68, Elsevier Oceanographic Series, Elsevier, 287-312.

Stramma, L., and F. Schott, 1999: The mean flow field of the tropical Atlantic Ocean. Deep-Sea Res., 46B, 279-303.

—, M. Rhein, P. Brandt, M. Dengler, C. Böning, and M. Walter 2005: Upper ocean circulation in the western tropical Atlantic in boreal fall 2000. Deep-Sea Res., 52, 221-240.

Townsend, T. L., H. E. Hurlburt, and P. J. Hogan, 2000: Modeled Sverdrup flow in the North Atlantic from 11 different wind stress climatologies. Dyn. Atmos. Oceans, 32, 373-417.

Visbeck, M., 2002: Deep velocity profiling using lowered acoustic Doppler current profilers: Bottom track and inverse solutions. J. Atmos. Oceanic Technol., 19, 794-807.

Zhang, D., M. J. McPhaden, and W. E. Johns, 2003: Observational evidence for flow between the subtropical and tropical Atlantic: The Atlantic tropical cells. J. Phys. Oceanogr., 33, 1783-1797. 